\title{
COVID-19 Pandemic and MSMEs in Indonesia: Impact and Policy Responses ${ }^{\star}$
}

\author{
Ahmad Dading Gunadi ${ }^{a}$, Harry Lesmana ${ }^{a}$, Hilda Fachrizah ${ }^{\text {, }}$ \\ Mohamad D. Revindo ${ }^{\mathrm{c}, *}$, \& Rama V. Daniswara ${ }^{\mathrm{b}}$ \\ ${ }^{a}$ The Ministry of National Development Planning/National Development Planning Agency, \\ the Republic of Indonesia (Bappenas) \\ ${ }^{b}$ Institute for Economic and Social Research, Faculty of Economics and Business, Universitas Indonesia \\ (LPEM FEB UI) \\ ${ }^{c}$ European Studies Program, the Graduate School of Strategic and Global Studies, Universitas Indonesia
} (SKSG UI)

\begin{abstract}
Since the first confirmed ca se of COVID-19 infection in Indonesia in March 2020, the pandemic has hit the economy hard, especially the Micro, Small and Medium-sized Enterprises (MSMEs). This study aims to analyze the extent of the impact of the pandemic on MSMEs and the effectiveness of the government policy measures. Primary data was collected through a questionnaire administered to 2,535 MSMEs in 17 provinces during July-September 2020. The results show that MSMEs already suffered revenue slump within the second month of the pandemic and encountered both financial and non-financial hardships. The government supports and assistance was perceived as very helpful to mitigate the impact of the pandemic by the recipients. However, the programs' distribution was hampered by either mis-targeting or lack of socialization regarding application requirements, procedures and registration location. The policy, academic and managerial implications of the findings are provided.
\end{abstract}

Keywords: MSMEs; COVID-19 pandemic; impact mitigation; government assistance; Indonesia

JEL Classification: H53; M21

*This article is a part of the "Pandemic Impact Mitigation for MSMEs in Indonesia" study conducted by the National Development Planning Agency/Ministry of National Development Planning (Bappenas), the Republic of Indonesia, in collaboration with Asosiasi Business Development Services Indonesia (ABDSI) and Kolaborasi Masyarakat dan Pelayanan untuk Kesejahteraan (KOMPAK).

${ }^{*}$ Corresponding Address: Gedung Ali Wardhana, UI Salemba Campus, Jl Salemba 4, Jakarta Pusat. E-mail: revindo.md@gmail.com. 


\section{Introduction}

Micro, Small and Medium-sized Enterprises (MSMEs) play an important role in Indonesia's economy, contributing $99.9 \%$ of business establishments, $60.51 \%$ of GDP and 96.92\% employment opportunities (Ministry of Cooperatives and SMEs, 2020). In the past, MSMEs in Indonesia have also shown resilience to economic turmoil, such as the 1997/98 Asian economic crisis and the 2008/09 global financial crisis (Sandee et al., 2000; Mavrodieva et al., 2019). Nevertheless, the COVID-19 outbreak starting March 2020 has brought an economic crisis with a higher level of complexity to MSMEs worldwide (Cowling et al., 2020). Reduced people activities and mobility due to fear of virus transmission and the social restrictions imposed by the government have hindered MSMEs' offline activities (Reardon et al., 2020). ${ }^{1}$ Baldwin \& di Mauro (2020) argued that the pandemic affects both the demand (i.e., consumer's purchasing power) and supply sides (e.g., raw materials and labor mobility) of the market. Subsequently, the pandemic has severely affected MSMEs' business, resulting in decreasing revenue or business closures.

ILO (2020) reported that out of 571 surveyed MSMEs in Indonesia, 68\% experienced disruptions in business activities, 65\% ceased operations, and 3\% went out of business. Also, in Indonesia, ABDSI (2020) reported that among 6,405 surveyed MSMEs, $48.3 \%$ had difficulty maintaining supply lines, $92.6 \%$ needed debt restructuring, and $26.6 \%$ experienced cash flow problems resulting in indebtedness. Most of those staying in business lost a large share of revenue; $28 \%$ lost half of their revenues.

By August 2020, the unemployment rate in Indonesia has reached 7.07\% (BPS-Statistics Indonesia, 2020) and, by November 2020, the number of workers affected by layoffs already reached 9.77 million (detikNews, 2020). The layoffs consequently increased the number of people falling below the poverty line. It was estimated that should Indonesia's economy only grew by $1 \%$ in 2020 , the poverty rate will rise to $12.4 \%$, equivalent to an additional 8.5 million more people falling into poverty (Suryahadi et al., 2020).

This paper aims to conduct a comprehensive investigation on the impact of the COVID-19 pandemic on MSMEs in Indonesia. More specifically, this paper aims to: (1) Investigate the extent to which the pandemic affects MSMEs business and operational performances across business scale, business sector, region and owner's gender; (2) Investigate the types of financial and non-financial hardships encountered by MSMEs; (3 Examine the accessibility of government economic assistance program for MSMEs; and (4) Examine the effectiveness of the government support programs in mitigating the impact of the pandemic in MSMEs.

Despite a number of studies previously investigated the impact of the pan-

\footnotetext{
${ }^{1}$ In 2020, the Indonesian government imposed large-scale social restrictions on certain activities of residents in several areas with a high number of COVID-19 infections.
} 
demic on MSMEs in Indonesia, there are still gaps in the extant literature to be filled, which also underline the contributions of this study. First, previous studies mostly drew a small sample of MSMEs or discussed specifically certain areas and sectors, while by contrast, this study sampled 2,535 MSMEs across different economic sectors in 17 provinces throughout Indonesia. Second, the extant studies mostly partially investigated the effectiveness of certain government support programs, while by contrast, this study examined various government support programs across ministries/agencies related to the mitigation of the pandemic impact on MSMEs.

The remainder of this paper is structured as follows. The second section briefly reviews the relevant extant and recent literature. The third section explains the research methodology, including the data collection and data analysis methods. The fourth section provides and discusses the results, while the last section concludes.

\subsection{MSMEs in Indonesia Prior to the Pandemic}

After the 1998 Asian Financial Crisis (AFC), most of Indonesian MSMEs were able to sustain their business activities better than their larger counterparts did (ter Wengel \& Rodriguez, 2006; Mavrodieva et al., 2019). The resilience was mainly due to their small-scale production assets and manual production techniques. MSMEs were also less dependent on third-party (especially foreign) investments to continue their business activities and were, therefore, less affected by the currency and exchange rate crises.

Prior to the pandemic, MSMEs were able to contribute significantly to the Indonesian economy by constituting $99.9 \%$ business establishments and 96.92 employment provision, but less dominant contribution in terms of GDP (60.51\%), investment $(60.03 \%)$ and export (15.65\%) (Ministry of Cooperatives and SMEs, 2020). Hence, previous studies were mainly divided into two streams of research. The first area of research focused on the effort to scale up MSMEs business operation including, but not limited to access to finance (see, for example, Rosavina et al., 2019; Susan, 2020; Revindo \& Gan, 2017) and effectiveness of government support (see for example Hill, 2002; Tambunan, 2007; Revindo et al., 2019a,c). The second area of research focused on MSMEs' internationalization, including but not limited to networking, market access, entrepreneurship and product competitiveness (see, for example, Tambunan, 2009; Revindo et al., 2017,2019b; ter Wengel \& Rodriguez, 2006; Sulistiyani \& Rahardja, 2018; Rekarti et al., 2018; Bhasin \& Venkataramany, 2010).

\subsection{MSMEs and the COVID-19 Pandemic}

\subsubsection{Government Supports for MSMEs}

In order to mitigate the impact of the pandemic on MSMEs, the government of Indonesia launched the national economic recovery program (PEN), aimed 
at various sectors in the economy, including MSMEs. The PEN programs for MSMEs are detailed in Table 1. The support programs mostly focused on the financial aspects of MSMEs' business.

Table 1: Government Supports for MSMEs in Mitigating the Pandemic's Impact

\begin{tabular}{|c|c|c|c|c|}
\hline No & Program & Legal Basis & Allocation & Recipient \\
\hline 1 & $\begin{array}{l}\text { Postponement of } \\
\text { loan's principal and } \\
\text { interest repayment }\end{array}$ & $\begin{array}{l}\text { POJK } \\
11 / \text { POJK.03/2020 }\end{array}$ & $\begin{array}{l}\text { No specific allo- } \\
\text { cation }\end{array}$ & $\begin{array}{l}\text { Existing People's Credit (KUR) } \\
\text { debtors ( } 11.8 \text { million borrowers) } \\
\text { and ultra-micro business credit } \\
\text { (11.4 million borrowers) }\end{array}$ \\
\hline 2 & $\begin{array}{l}\text { Interest subsidy for } \\
\text { MSMEs' loans }\end{array}$ & $\begin{array}{l}\text { PMK } \\
65 / \text { PMK.05/2020 }\end{array}$ & IDR35.2 trillion & $\begin{array}{l}\text { MSMEs, identified by the respec- } \\
\text { tive banks }\end{array}$ \\
\hline 3 & Tax incentives & PMK 44/2020 & $\begin{array}{l}\text { IDR120.61 tril- } \\
\text { lion }\end{array}$ & All eligible businesses \\
\hline 4 & $\begin{array}{l}\text { Regional cash incen- } \\
\text { tives }\end{array}$ & $\begin{array}{l}\text { PMK 19/2020; PMK } \\
\text { 114/2020 }\end{array}$ & IDR13.5 trillion & 171 regions in Indonesia \\
\hline 5 & $\begin{array}{l}\text { Working capital } \\
\text { stimulus }\end{array}$ & PMK 71/2020 & IDR125 trillion & $\begin{array}{l}\text { Export-oriented MSMEs and } \\
\text { firms in certain industries }\end{array}$ \\
\hline 6 & $\begin{array}{l}\text { Working capital } \\
\text { credit guarantee }\end{array}$ & PMK 71/2020 & IDR6 trillion & $\begin{array}{l}\text { MSMEs with the prospect to jump } \\
\text { start under new normal condi- } \\
\text { tions }\end{array}$ \\
\hline 7 & $\begin{array}{l}\text { State fund place- } \\
\text { ment in banks }\end{array}$ & PMK 70/2020 & IDR30 trillion & $\begin{array}{l}\text { State-owned banks, to be re- } \\
\text { channeled to MSMEs }\end{array}$ \\
\hline 8 & $\begin{array}{l}\text { Productive presiden- } \\
\text { tial aid }\end{array}$ & $\begin{array}{l}\text { Regulation of the } \\
\text { Minister of Cooper- } \\
\text { atives and SMEs No. } \\
6 / 2020\end{array}$ & IDR28.8 trillion & 12 million MSMEs \\
\hline
\end{tabular}

\subsubsection{National Economic Recovery Program}

The central government of Indonesia allocated IDR695.2 trillion PEN program funds in 2020, IDR123.46 trillion of which was allocated specifically for pandemicimpact mitigation and business recovery of MSMEs (Ministry of Finance, 2020). Figure 1 shows the development of PEN program realization in which IDR30.22 trillion had been channeled to the beneficiaries by Q2-2020. In July, only an additional IDR0.98 trillion was channeled and significant additional disbursement was recorded again in August and September. Only by the end of 2020, the realization of the PEN program funds picked up and reached $82.83 \%$ of the allocated budget. As for the PEN funds for MSMEs, IDR112.44 trillion has been channeled in 2020 , or more than $90 \%$ of the allocated budget.

\subsubsection{Economic Growth Scenarios}

Due to the large role of MSMEs in Indonesia's economy, the decline of MSMEs business during the pandemic and the late PEN program fund distribution was also reflected in national economic growth throughout 2020 (Figure 2). The economy still recorded positive but very low growth in Q1-2020 at 2.97\% y-o-y. 


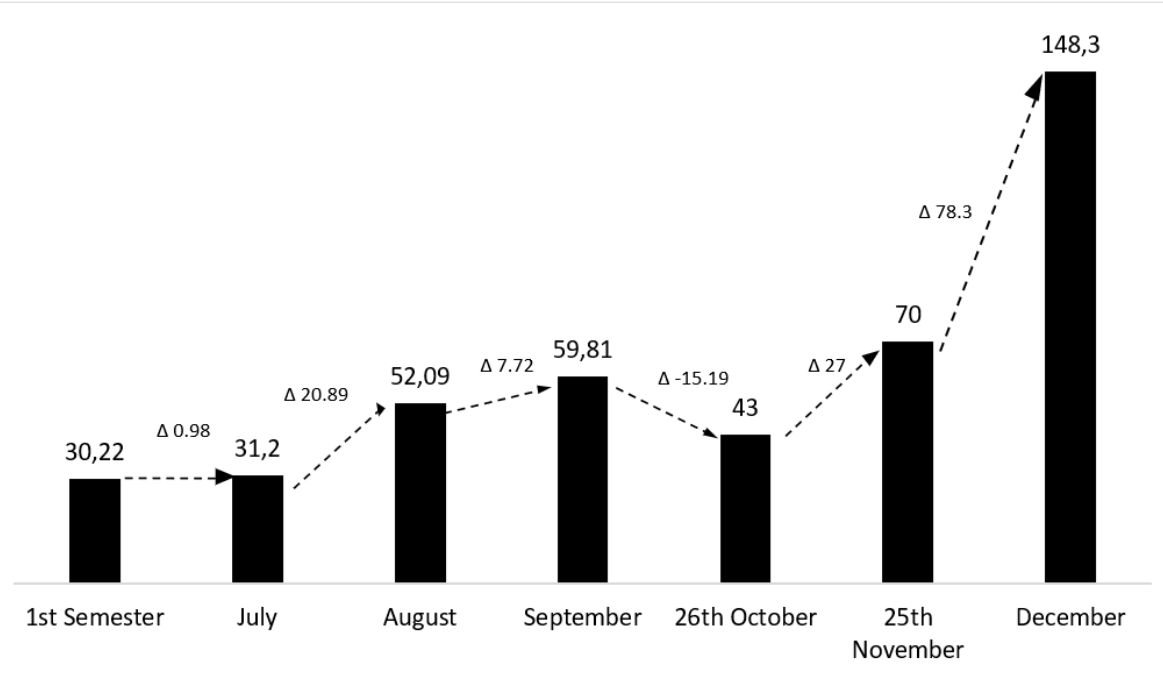

Figure 1: Disbursement of the PEN Program Funds (in trillion IDR) Source: Ministry of Finance (2020)

However, the sharp fall in MSMEs turnover in April and May and the delay in PEN program fund distribution led to consecutive economic contractions during the second and third quarters of 2020 , amounting to -5.32 and $-3.49 \%$, respectively.

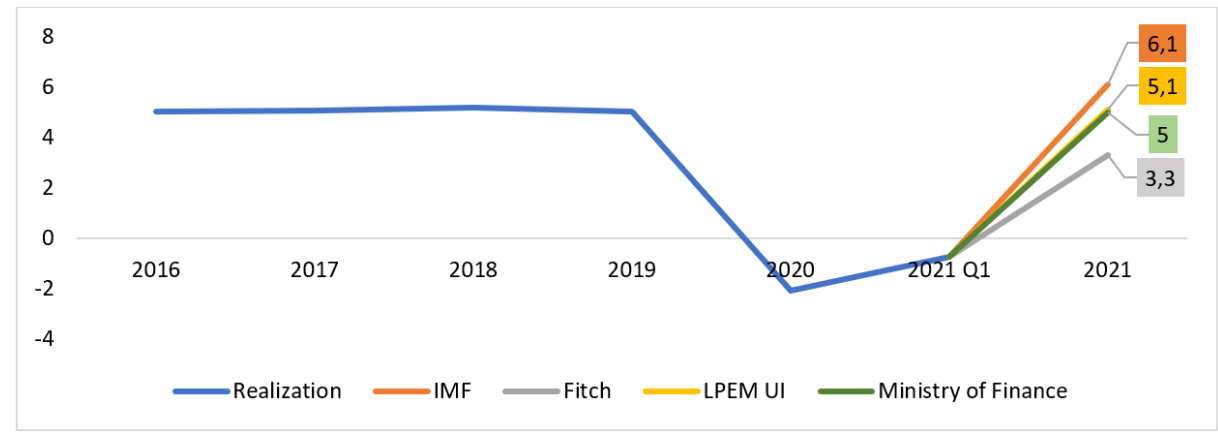

Figure 2: Economic Growth Scenarios

Source: Various sources compiled by the authors

Figure 2 also portrayed the national and international institutions projection on Indonesia's economic growth in the last quarter of 2020, all predicted contraction to persist and the economy was only expected to recover in 2021. However, 
the actual growth of Q4-2020 was recorded at -2.19\% (Bank Indonesia, 2021), while contrary to the prediction in Q1-2021, it still recorded negative growth of 0.74\% y-o-y (BPS-Statistics Indonesia, 2021).

\section{Methodology}

\subsection{Conceptual Framework}

Figure 3 depicts the conceptual framework employed in this study. The analysis of the impact of the pandemic on MSMEs incorporates the short-term immediate impact (during the pandemic) and business recovery period.

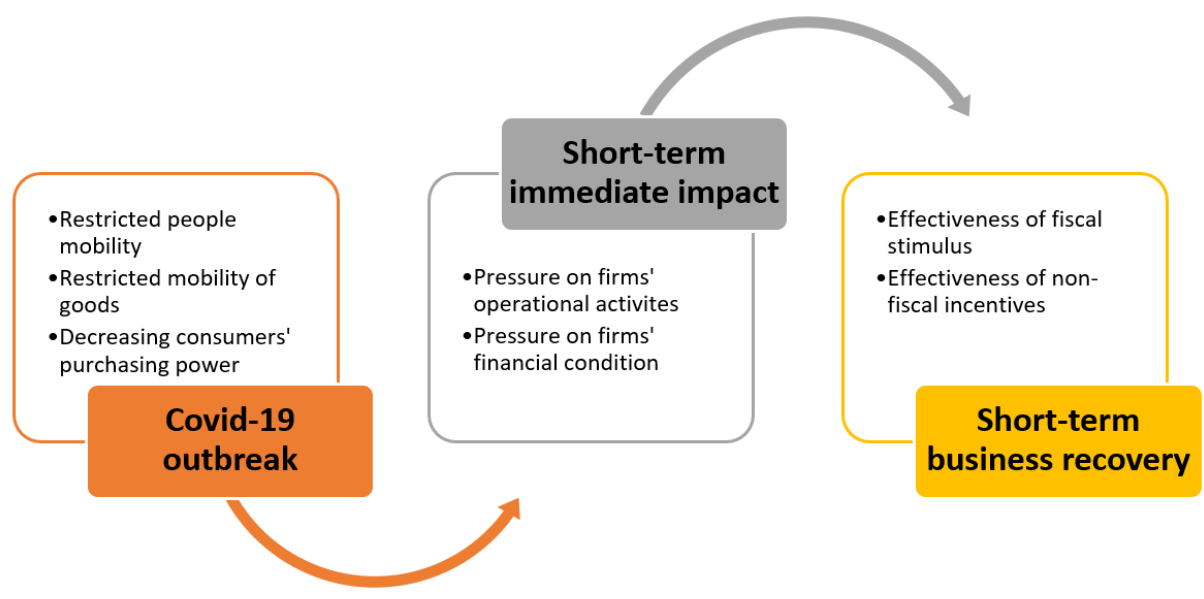

Figure 3: Study Analytical Framework

\subsection{Data}

The study relies mainly on primary data collected through a survey administered using a questionnaire during August-September 2020. The survey targeted to sample MSMEs representing various regions, business scale, business sectors and owners' gender. $^{2}$ The survey yielded 2,535 usable responses and Table 2 shows the distribution of the responses. Table 2.a shows that the sample was obtained from 17 provinces, with Jawa and Sumatera Islands are each represented by three provinces while Kalimantan, Sulawesi, Bali-Nusa Tenggara and Papua-Maluku

\footnotetext{
${ }^{2}$ MSMEs are defined as enterprises employing less than 100 workers (BPS-Statistics Indonesia, 2014) or having assets valued at a maximum IDR10 billion (excluding land and buildings) or having an annual turnover of maximum IDR50 billion (Law on Micro, Small and Medium-sized Enterprise Number 20 of 2008).
} 
are each represented by two provinces. In terms of business scale, the sample comprises $55 \%$ micro, $40 \%$ small, and 5\% medium-sized businesses. In terms of business sector, Table 2.b shows that the sample covers various business activities. However, it is worth noting that the total number of responses by the business sector $(2,735)$ exceeds the number of MSMEs as each firm may have more than one product or service. In addition, the female owners constitute $52.43 \%$ of the sample as compared to $47.57 \%$ male owners.

Table 2.a: Survey Responses Distribution by Province and Business Scale

\begin{tabular}{lcccc}
\hline \hline Province & Micro Enterprises & Small Enterprises & Medium Enterprises & Total \\
\hline Aceh & 62 & 55 & 6 & 123 \\
Sumatera Utara & 129 & 25 & 3 & 157 \\
Sumatera Barat & 94 & 34 & 11 & 139 \\
Jawa Barat & 191 & 111 & 22 & 324 \\
Yogyakarta & 184 & 123 & 11 & 318 \\
Jawa Timur & 223 & 149 & 26 & 398 \\
Bali & 42 & 21 & 10 & 73 \\
NTT & 215 & 30 & 6 & 251 \\
Kalimantan Barat & 207 & 40 & 15 & 262 \\
Kalimantan Tengah & 46 & 15 & 0 & 61 \\
Kalimantan Utara & 0 & 2 & 0 & 2 \\
Sulawesi Tengah & 57 & 30 & 2 & 89 \\
Sulawesi Selatan & 57 & 41 & 9 & 107 \\
Sulawesi Tenggara & 9 & 7 & 0 & 16 \\
Maluku & 112 & 37 & 1 & 150 \\
Papua Barat & 11 & 1 & 0 & 12 \\
Papua & 24 & 18 & 11 & 53 \\
\hline Total & 1,663 & 739 & 133 & 2,535 \\
Distribution & $65,60 \%$ & $29,20 \%$ & $5,20 \%$ & $100 \%$ \\
\hline Source: Survey Data & & & & \\
\hline
\end{tabular}

Source: Survey Data

In order to complement the survey data, focus group discussions (FGD) and interviews were also carried out to formulate policy recommendations involving various stakeholders at the national level. The stakeholders included Coordinating Ministry for Economic Affairs, Ministry of Finance, Ministry of Social Affairs, Ministry of Cooperatives and SMEs, Ministry of Industry, Ministry of Trade, Ministry of Villages and Transmigration, Bank Indonesia, Non-government organizations (NGOs), academics, SME associations and research institutes.

\subsection{Data Analysis Methods}

This study uses mainly descriptive statistics and qualitative approaches. The variables processed from the questionnaire were analyzed using descriptive statistical methods to obtain complete pictures about MSMEs during the pandemic. 
Table 2.b: Survey Responses Distribution by Region and Business Scale

\begin{tabular}{|c|c|c|c|c|c|c|}
\hline & \multicolumn{6}{|c|}{ Region } \\
\hline & Sumatera & $\begin{array}{c}\text { Jawa } \\
\text { and } \\
\text { Bali }\end{array}$ & Kalimantan & Sulawesi & $\begin{array}{l}\text { NTT } \\
\text { Maluku } \\
\text { Papua }\end{array}$ & Total \\
\hline $\begin{array}{l}\text { Agriculture, Fishery, } \\
\text { Plantation }\end{array}$ & 70 & 209 & 43 & 33 & 85 & 440 \\
\hline Processing industry & 196 & 478 & 116 & 111 & 140 & 1,041 \\
\hline $\begin{array}{l}\text { Wholesale and Retail } \\
\text { Trade, Repair and } \\
\text { Maintenance of Cars and } \\
\text { Motorcycles }\end{array}$ & 75 & 200 & 82 & 31 & 104 & 492 \\
\hline $\begin{array}{l}\text { Provision of Accommodation } \\
\text { and Provision of Food and } \\
\text { Drink }\end{array}$ & 57 & 179 & 63 & 40 & 73 & 412 \\
\hline $\begin{array}{l}\text { Transportation, Warehousing, } \\
\text { and Other Services }\end{array}$ & 48 & 110 & 40 & 16 & 67 & 281 \\
\hline Others & 9 & 26 & 17 & 11 & 6 & 69 \\
\hline Total & 455 & 1,202 & 361 & 242 & 475 & 2,735 \\
\hline
\end{tabular}

Source: Survey Data

\section{Results}

\subsection{Impact of the Pandemic on MSMEs}

\subsubsection{Impact on Revenue}

Most of the surveyed MSMEs recorded a decline in revenue due to the pandemic outbreak. However, revenue drop varied across firm size, business sector, region and gender. In terms of firm size, the bigger the scale, the deeper the drop in revenue (Figure 4.a). A considerable share of medium-sized firms recorded $60-80 \%$ revenue losses, while the micro and small-sized firms mostly recorded 40-60\% revenue drops as compared to pre-pandemic period.

In terms of business sector, the deep impact was recorded by MSMEs in the transportation and warehousing sector, $23 \%$ of which reported a revenue decline of more than $80 \%$ (Figure $4 . b$ ). This can be explained by various social restrictions imposed by the government in 2020. The majority of MSMEs in five other sectors experienced either $60-80 \%$ or $40-60 \%$ loss of revenue. In terms of region, almost half of the surveyed MSMEs in Sumatera suffered either more than $80 \%$ or $60-80 \%$ revenue loss, while those in four other regions suffered either $40-60 \%$ or $60-80 \%$ revenue loss (Figure 4.c). In terms of gender, more female owners suffered the loss of $60 \%$ or more revenue than their male counterparts did, while more male than female owners suffered moderate revenue loss.

\subsubsection{Impact on Profit Margin}

Most of the surveyed MSMEs recorded a decline in profit margin due to the pandemic outbreak. However, the lower profit margin varied across firm size, 


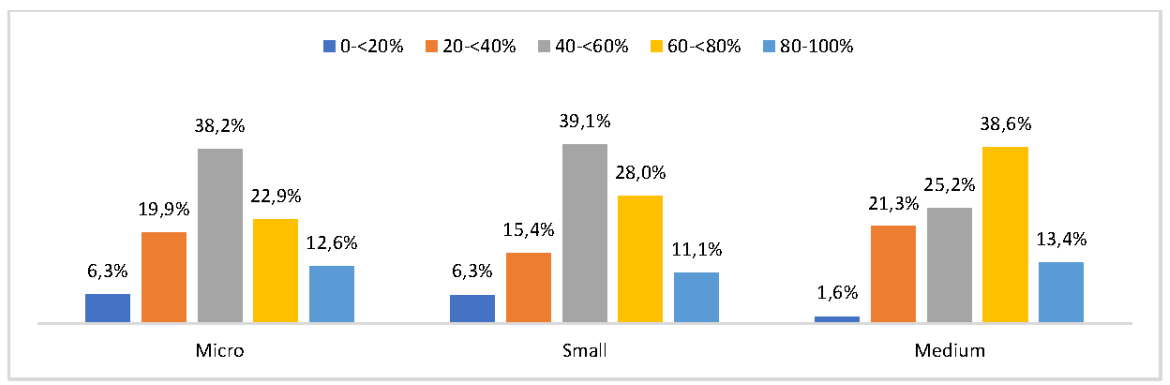

(a) By business scale

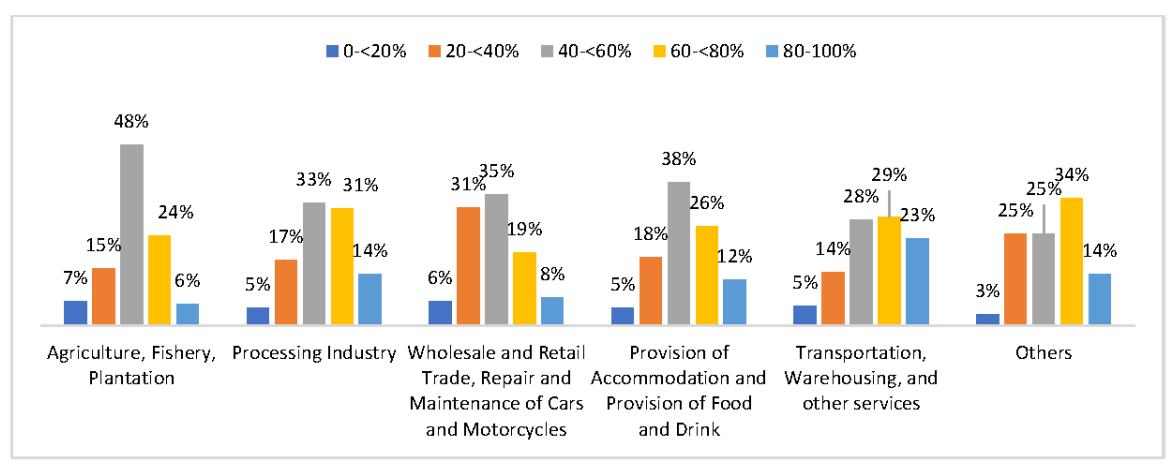

(b) By business sector

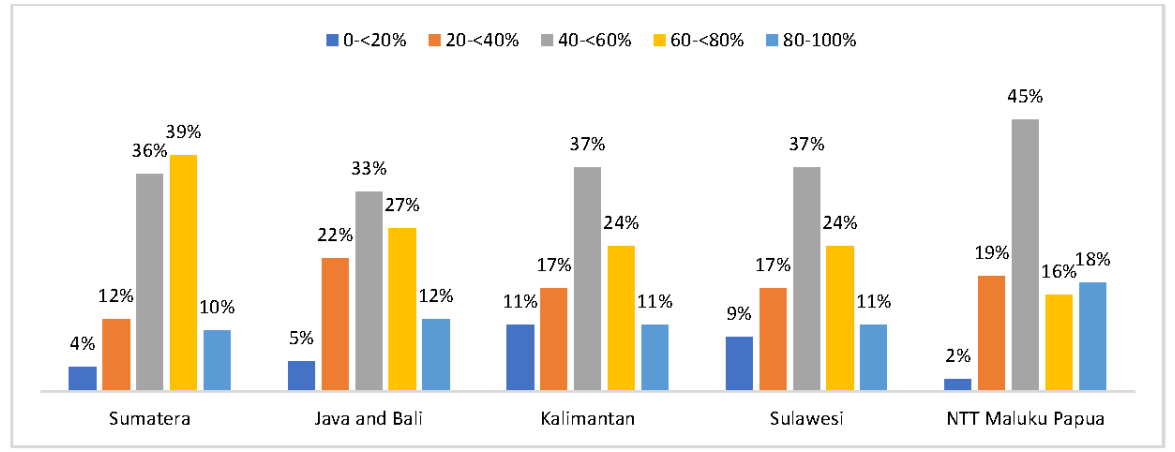

(c) By region

Figure 4: Decrease in MSMEs' Revenue

Source: Survey Data

business sector, region and gender. In terms of firm size, the bigger the scale, the deeper the drop in profit margin (Figure 5.a). A considerable share of mediumsized firms recorded $60 \%-80 \%$ lower profit margins, while the micro and smallsized firms mostly recorded $40 \%-60 \%$ profit margin cut as compared to the 
pre-pandemic period.

In terms of business sector, the large profit margin reduction was recorded by MSMEs in the transportation and warehousing as well as manufacturing sectors (Figure 5.b), while most of MSMEs in four other sectors experienced a moderate decline in profit margin. In terms of region, a large share of surveyed MSMEs in Sumatera suffered $60 \%-80 \%$ lower profit margin while those in four other regions suffered either $20 \%-40 \%$ or $40 \%-60 \%$ lower profit margin. In terms of gender, more female owners suffered a loss of $60 \%$ or more profit margin than their male counterparts did, while more male than female owners suffered moderate profit margin cuts.

\subsubsection{Other Financial Hardships}

Figure 6 shows various types of financial hardships encountered by surveyed MSMEs due to the pandemic. Five main problems commonly observed across firm scale, business sector, region and owners' gender were wages/salaries for employees, fixed expenses (store rental, warehousing), payment of bills/operational costs, payment of accounts payable and other expenses. Three less problematic challenges included payment of insurances, bank loans, and other problems.

In addition, several specific findings were also observed. Workers' salary was less problematic for micro-scale firms, supposedly because most microenterprises are run by owners or employ few or part-time employees. Second, workers' salary was also less problematic for firms in the trading sector, as the sector is generally less labor-intensive than five other sectors. For trading firms, accounts payable appeared as a crucial problem, possibly because suppliers normally provide inventories. In terms of location, the financial problems varied across regions with no specific pattern. Interestingly, in terms of gender, those financial hardships were slightly less severe for female-owned than male-owned MSMEs.

\subsubsection{Non-financial Problems}

MSMEs' financial hardships were worsened by several non-financial challenges due to the pandemic. Figure 7 shows the change in the number of employed workers after several first months of the pandemic in 2020. Most of MSMEs had to lay off their workers, with the exception of the micro-enterprises that are mainly in the form of individual or family business. The reduction of employees was found in all business sectors, but regionally, the workers in Jawa, Bali and Sulawesi suffered the most. In terms of gender, the share of female-owned MSMEs that reported the reduction of employees was slightly lower than male-owned MSMEs.

Figure 8 shows other non-financial problems encountered by the surveyed MSMEs during the pandemic. Across the business scale, sectors, location, and owners' gender, three main challenges were reported: increasing prices of raw 


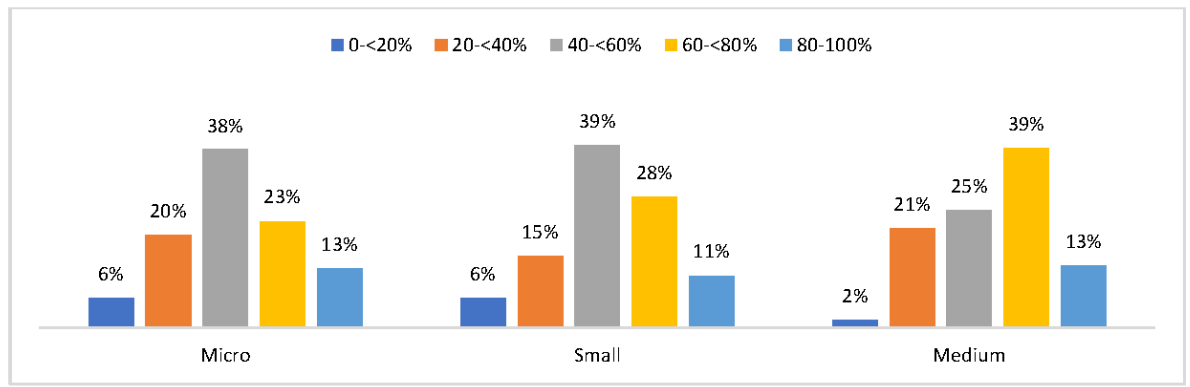

(a) By business scale

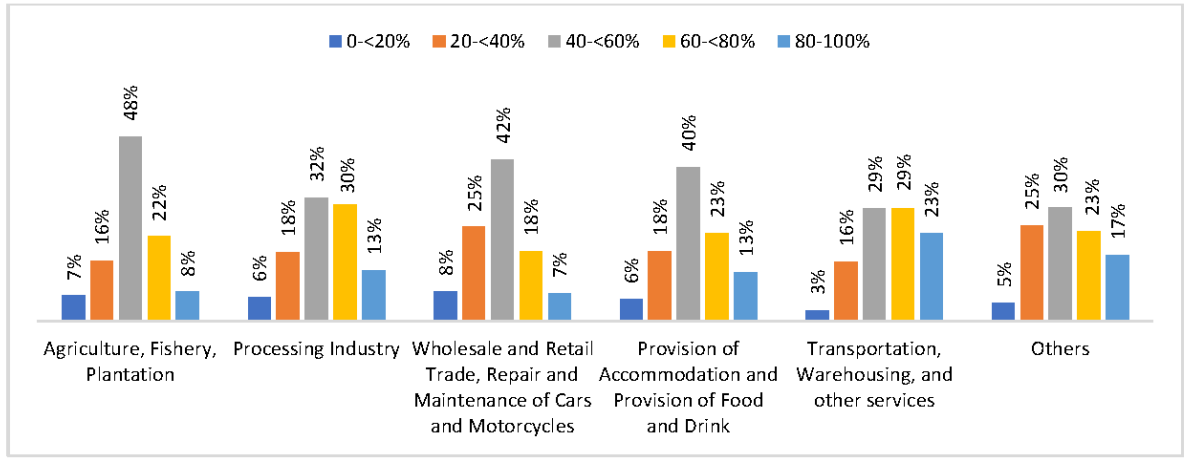

(b) By sector

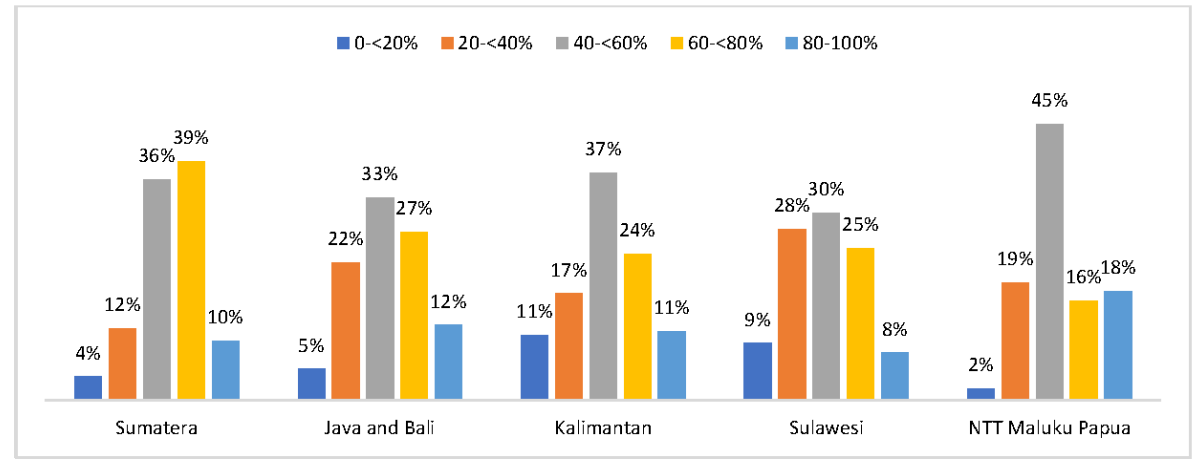

(c) By region

Figure 5: Decrease in MSMEs' Profit Margin

Source: Survey Data

materials/inputs, difficulties in distributing business products (logistics problems), and declining market demand. The logistical problems stem from the government's enactment of PSBB, which put high uncertainty on many logistics 


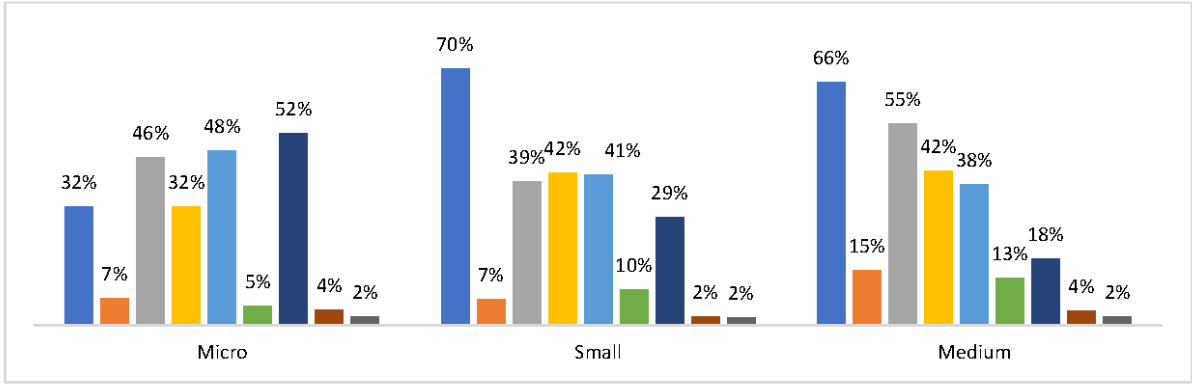

(a) By business scale

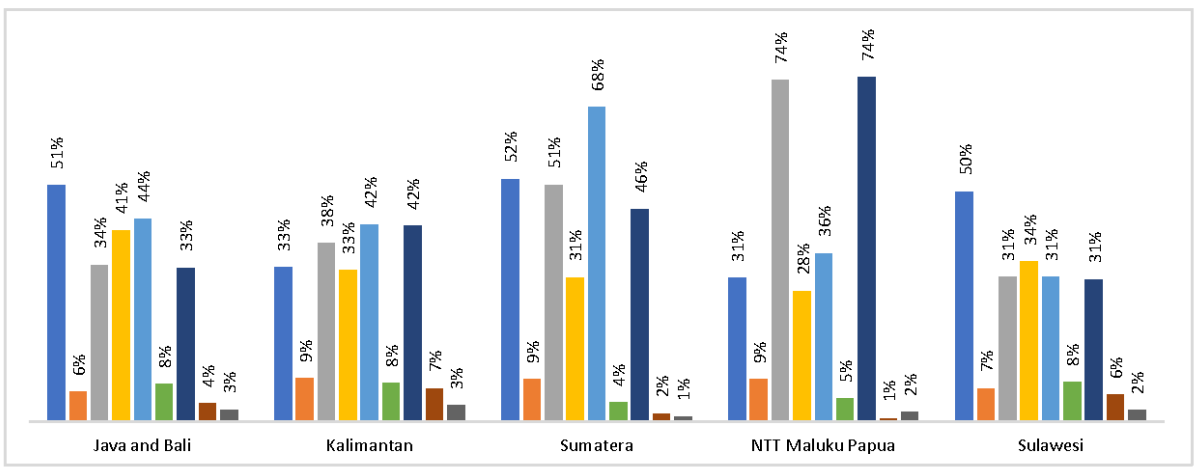

(b) By business sector

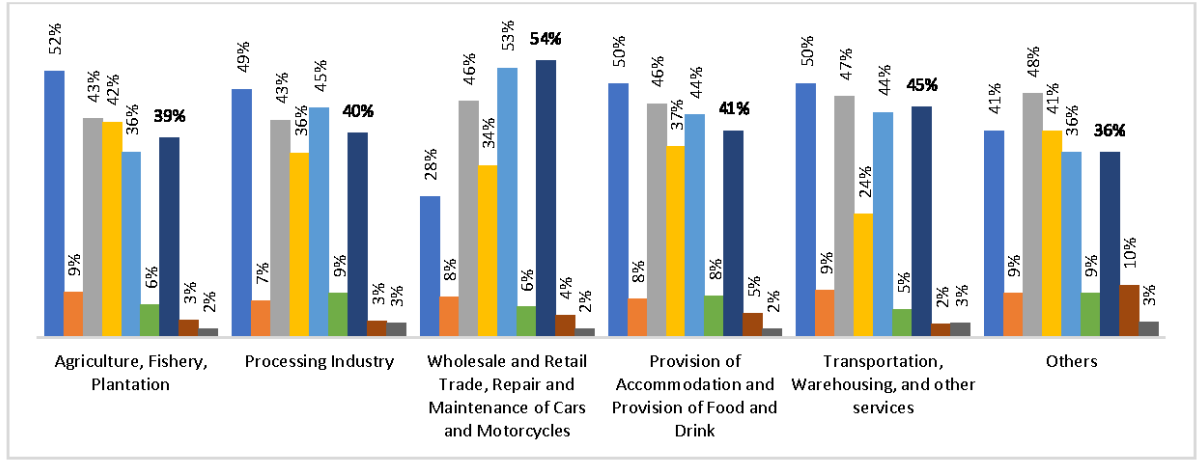

(c) By region

Note:

- Employees' salary

Insurance

Fixed costs

- Payment of accounts payable

Bills payment

- Bank loans repayment restructuring

Other expenses

- Others

No significant problems

Figure 6: Financial Hardships Encountered by MSMEs Source: Survey Data 
Increasing number of employees $\quad$ Decreasing number of employees No changes in employees

$$
\text { Micro }
$$

$72,0 \%$

0,0

$$
\text { Small }
$$

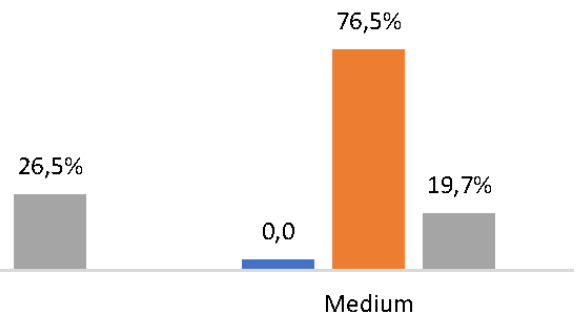

Medium

(a) By business scale

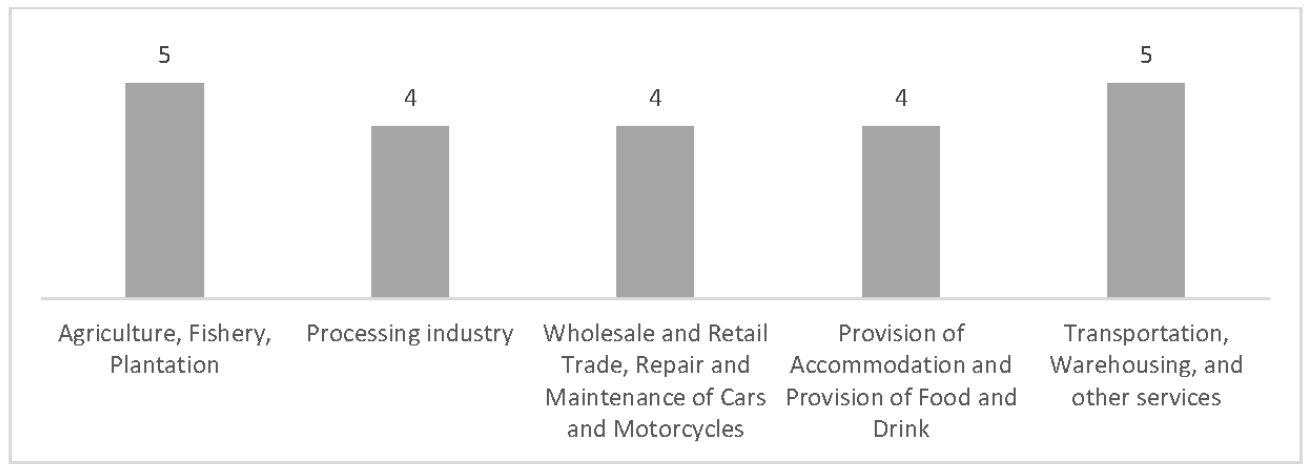

(b) Average employees' reduction (person) by business sector

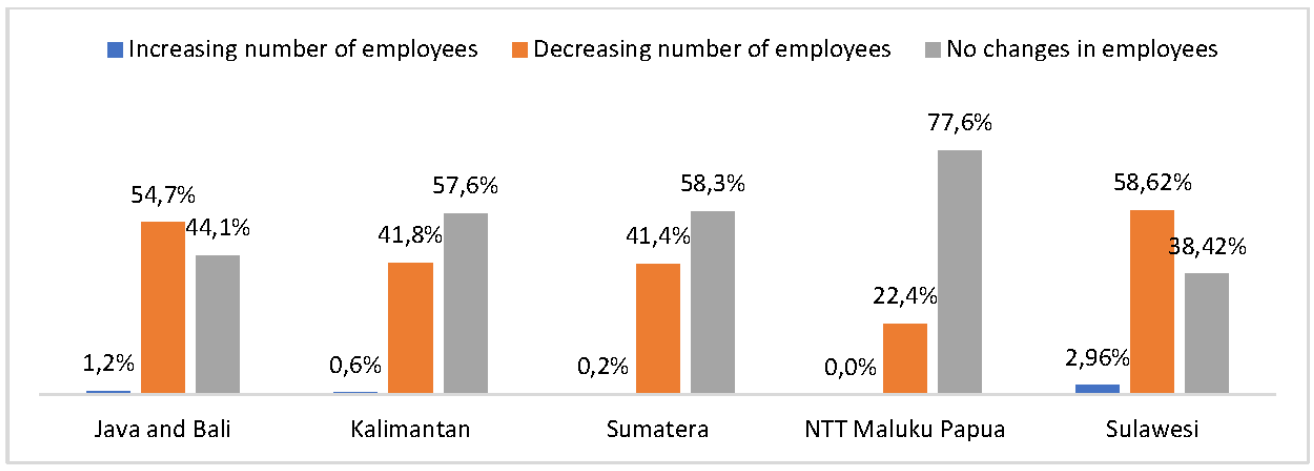

(c) By region

Figure 7: Changes in the Number of MSMEs' Employees

Source: Survey Data 
companies. The logistical problems were mainly evident in MSMEs operating in the agriculture sector and those in Jawa-Bali and Sumatera. These logistical problems also, to some extent, cause the increase in the price of raw materials/inputs as the PSBB caused bottlenecks in the supply chain, especially in distributing the upstream input productions.

The decline in demand and orders was due to nationwide massive layoff of employees, salary cut and salary payment postponement. Three other nonfinancial challenges were reported, despite being less problematic for MSMEs, including difficulties in obtaining raw materials, inability to meet the demand due to staffing problems, and difficulties in accessing health protection equipment (facemasks, hand sanitizer, gloves, etc.).

\subsection{Pandemic Scenario and MSMEs' Recovery}

While the previous section discusses the extent of the impact of the pandemic on MSMEs' revenue, the timing of the impact is also critical, as shown in Figure 9. MSMEs generally began to experience a decline in revenue already in March or April (Figure 9.a). Interestingly, a number of the medium-sized businesses only began to exhibit revenue decline during April-June, as they were more likely to have a medium or long-time production contract with their customer to fulfill.

If viewed by the business sector, MSMEs generally began to exhibit revenue decline in March, except those in the trade sector, which reported that the decline began in March and April (Figure 9.b). This is because during the first month of the pandemic, from the demand side, consumers still purchased groceries for consumption or precautions, while from the supply side, the MSME still had stocks to be sold in their shops. By region, generally, MSMEs began to exhibit revenue decline in March, except those in NTT, Maluku, and Papua, which reported the decline in March and April (Figure 9.c). This is possibly due to the low capacity for COVID-19 rapid tests in these areas, which led to low reported infection cases and late imposition of social distancing.

MSMEs' revenue then continued to decline in the months that followed until they reached the lowest monthly revenue before reaching the turnaround point, as shown in Figure 10. Micro and small-scale businesses generally reported the lowest revenue in April, but medium-sized enterprises experienced it in May (Figure 10.a). Medium-sized businesses are more likely to have internal and external resources to mitigate the impact of the pandemic than their smaller counterparts.

By business sector, MSMEs generally recorded the deepest revenue fall in April (Figure 10.b), including those in the trading sector. By April, household incomes and savings began to decrease while there were also delays in the delivery of raw materials from inter-region and imports. Likewise, in terms of region, MSME generally recorded the deepest revenue fall in April, including those in NTT, Maluku, and Papua (Figure 10.c). Interestingly, a considerable share of MSMEs in Jawa and Bali only recorded the lowest revenue in May, June and 


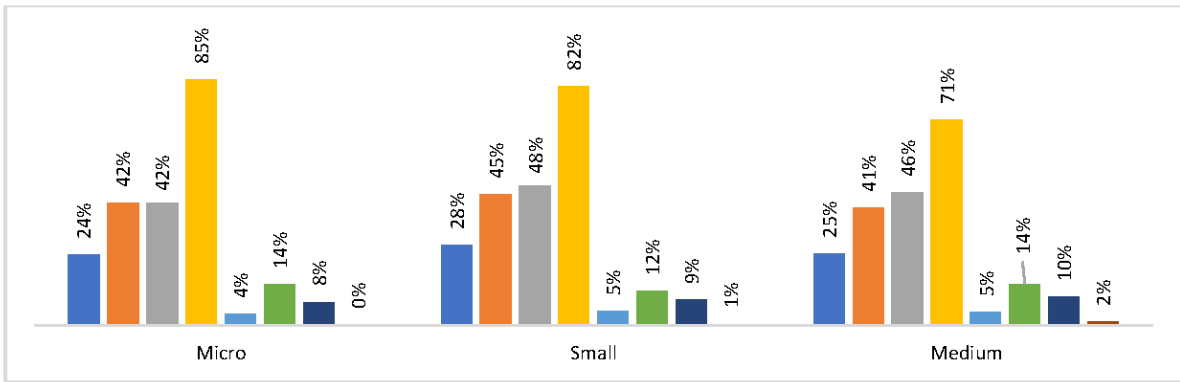

(a) By business scale

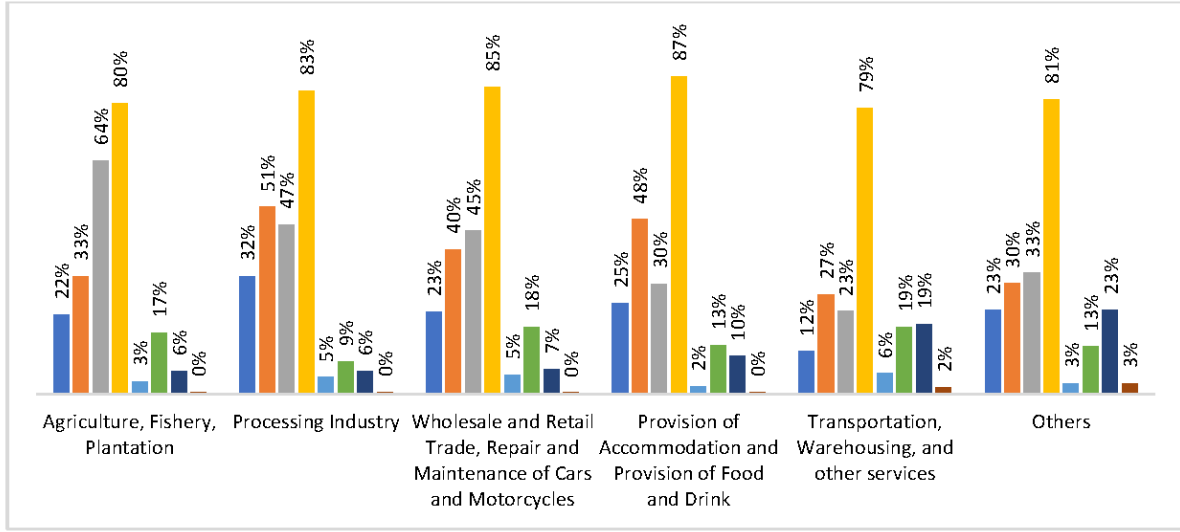

(a) By business sector

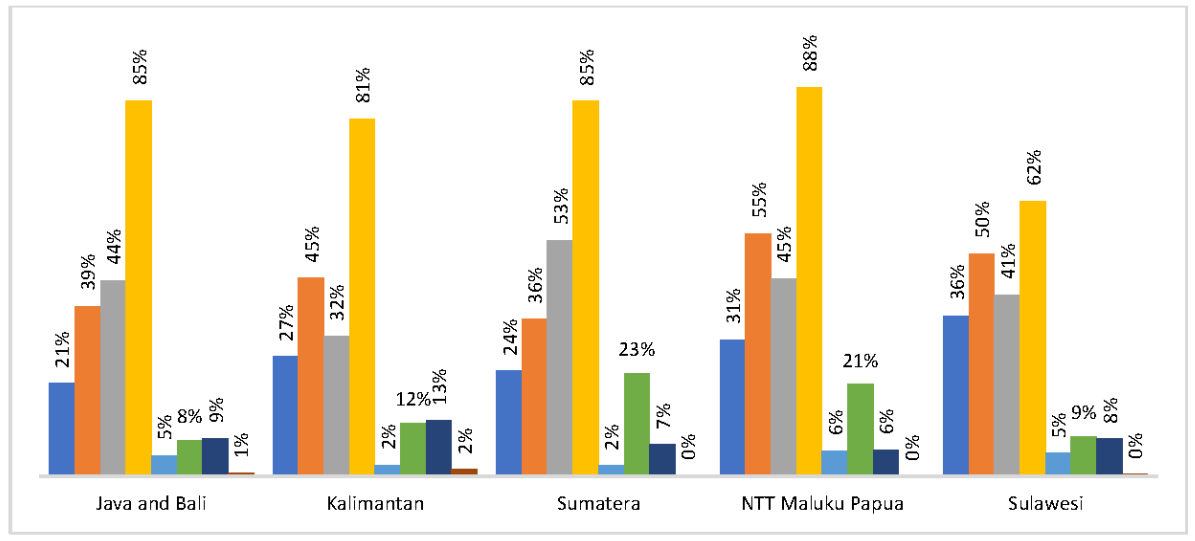

(c) By region

Note:

\begin{tabular}{|c|c|}
\hline Difficulty in obtaining raw materials & Unable to fulfill the orders due to labor shortage \\
\hline Increasing prices of raw materials & Eack of health protection equipment \\
\hline Difficulty in distributing the products (logistics problems) & mother problems \\
\hline
\end{tabular}

Figure 8: Non-Financial Problems Encountered by MSMEs Source: Survey Data 


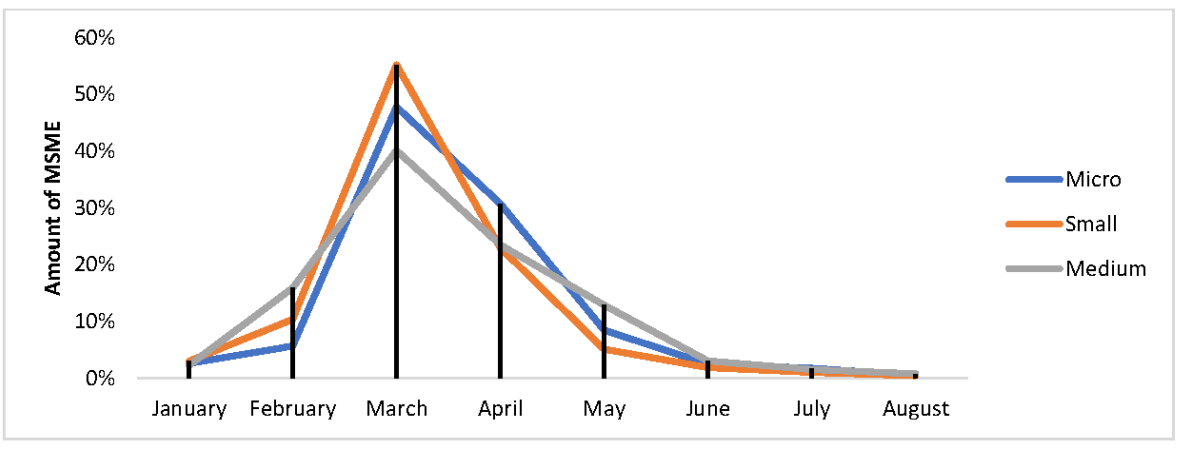

(a) By business scale

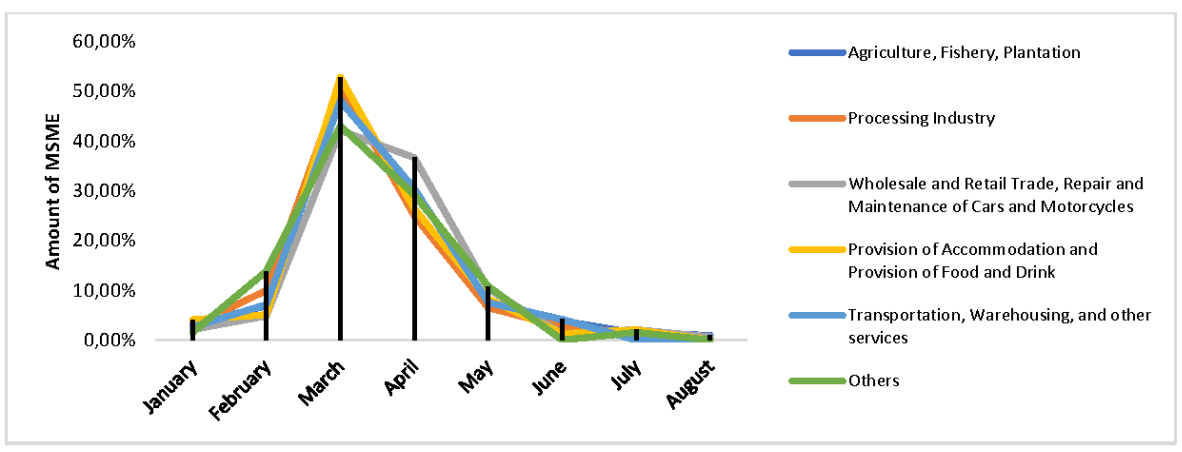

(b) By business sector

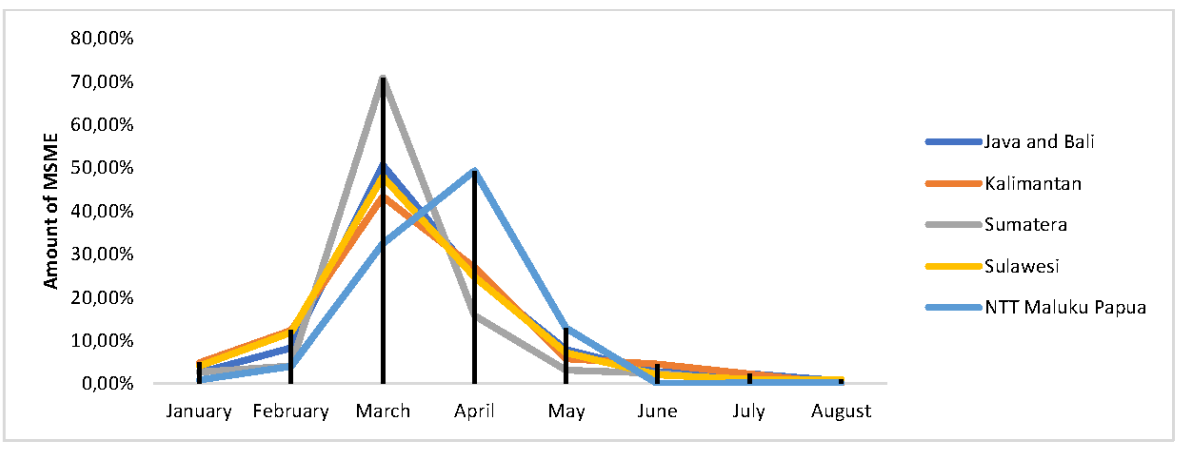

(c) By region

Figure 9: Beginning of MSMEs' Revenue Decline

Source: Survey Data

July. One possible explanation for this is their ability to adopt online marketing, coupled with good internet access and consumers' ability to switch to online purchases. 


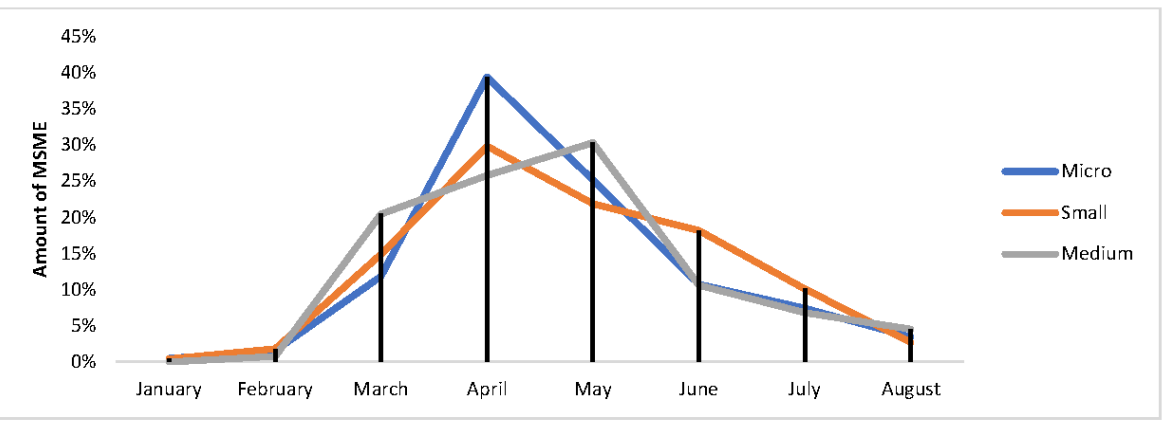

(a) By business scale

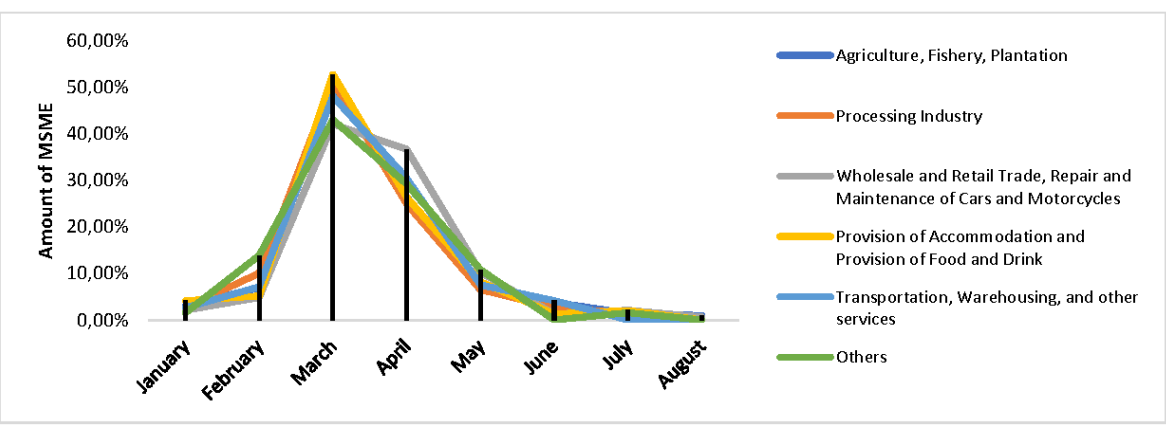

(b) By business sector

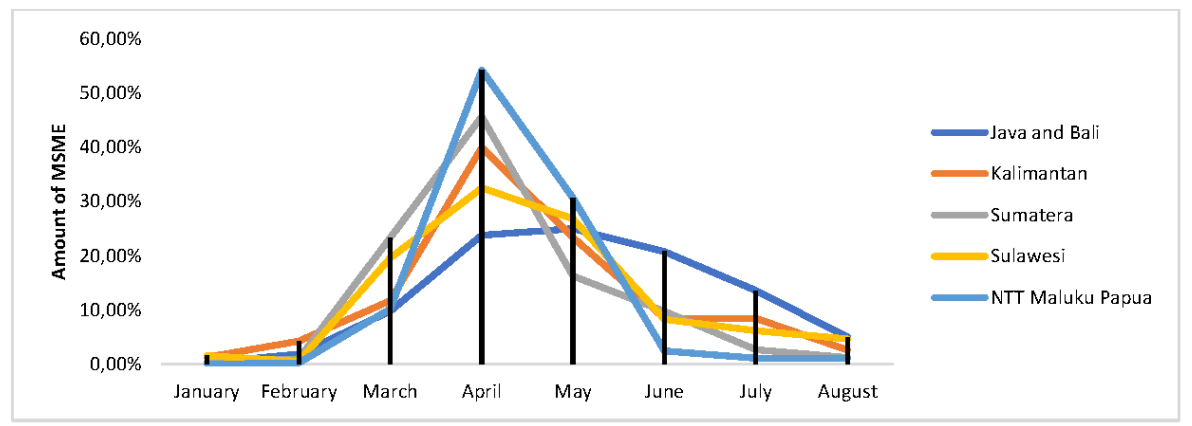

(c) By region

Figure 10: Lowest MSMEs' Revenue Period

Source: Survey Data

Figure 11 plot the period of the decline of MSMEs' revenue (beginning and the lowest points) in general (all scales, sectors, and regions) along with the disbursement of the government's National Economic Recovery (PEN) program. At least two types of gaps can be observed: (1) The time gap between the time the MSMEs need external assistance and the acceleration of PEN distribution and 
(2) The gap between the magnitude of the impact of the pandemic on MSMEs revenue and the level of PEN realization. The PEN disbursement was initially stalled due to database collection and liquidity problems before Regulation in Lieu of Law (Perppu) No. 1/2020 and Government Regulation (PP) 23/2020 were eventually approved by the parliament on March 31 and May 9, 2020, respectively.

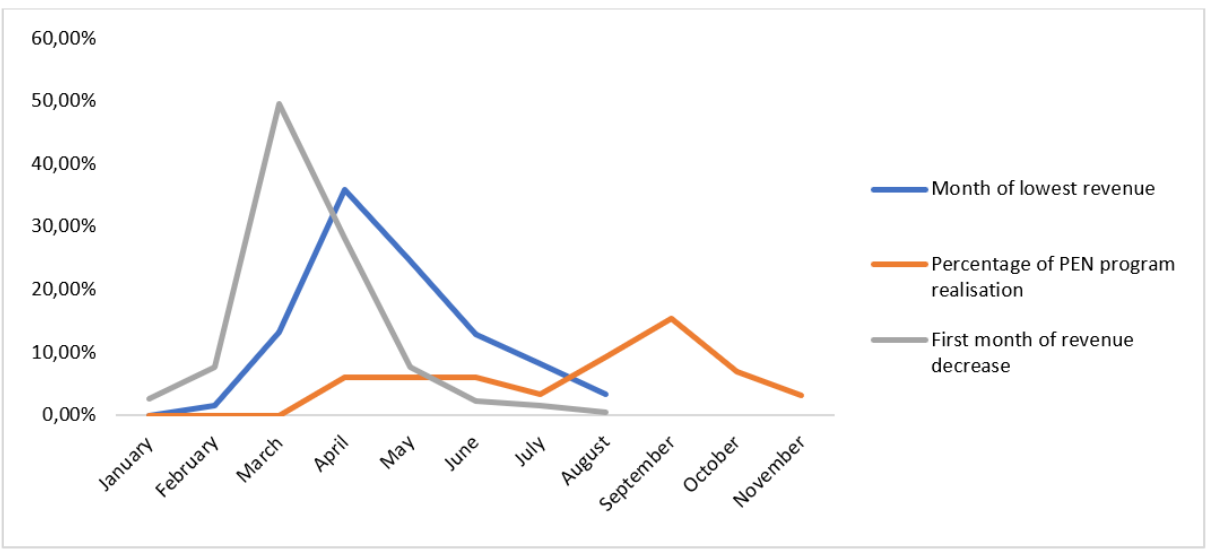

Figure 11: Timeline of MSMEs' Revenue Decline and PEN Disbursement Source: Survey data and Ministry of Finance

\subsection{Government Policies for Impact Mitigation and Economic Recovery}

Being one of the countries with the highest COVID-19 infection cases in ASEAN, Indonesia's households, financial services, corporates, and MSMEs were hit hard by the pandemic; with the latest suffered the greatest impact. In order to help MSMEs mitigate the pandemic's impact, maintain their operations, and assist them in recovering, in 2020, the government implemented social assistance policies and economic stimulus targeted to MSMEs nationwide. The government designed a national economic recovery program through the modalities regulated in Government Regulation Number 23 of 2020 (PP 23/2020) regarding the implementation of the PEN program, aimed at MSMEs, ultra-micro businesses, strategic business sectors in the economy and the State-owned Enterprises (SoEs), as illustrated in Table 3.

At the implementation level, however, the effectiveness of the programs for the beneficiaries should be evaluated. Table 4 shows surveyed MSMEs' perception of eight programs aimed for MSMEs, measured by their awareness, level of application/participation/registration and sources of information regarding the programs. Green boxes indicate higher than $75 \%$, while red boxes indicate 
Table 3: National Economic Recovery Design in 2020

\begin{tabular}{|c|c|c|c|c|}
\hline \multicolumn{3}{|c|}{ Q2 } & Q3 & Q4 \\
\hline \multirow{3}{*}{$\begin{array}{l}\text { Economic } \\
\text { Impact } \\
\text { Scenario }\end{array}$} & $\begin{array}{l}\text { Production } \\
\text { Impact } \\
\text { Baseline }\end{array}$ & $\begin{array}{l}\text { - Tourism halted (Transportation, Accommodation, } \\
\text { Restaurants) } \\
\text { - Trade \& commerce plunged sharply } \\
\text { - Manufacturing disrupted }\end{array}$ & & $\begin{array}{l}\text { - Tourism activities recovers } \\
\text { - } \text { Trade \& commerce pick up } \\
\text { resume }\end{array}$ \\
\hline & \multirow{2}{*}{$\begin{array}{l}\text { Consumption } \\
\text { Impact } \\
\text { Baseline }\end{array}$} & $\begin{array}{l}\text { - Social distancing significantly reduced public } \\
\text { consumption, in formal and informal sectors }\end{array}$ & \multicolumn{2}{|c|}{$\begin{array}{l}\text { Consumption activities gradually recovered (electronics, } \\
\text { clothing, restaurants, hotels, tourism, transportation, etc.) }\end{array}$} \\
\hline & & \multicolumn{2}{|c|}{ - Poverty and unemployment rose sharply (especially in informal sectors) } & Unemployment \& poverty \\
\hline \multirow{3}{*}{$\begin{array}{l}\text { Policy } \\
\text { Response } \\
\text { Design }\end{array}$} & $\begin{array}{l}\text { Consumer } \\
\text { Stimulus }\end{array}$ & $\begin{array}{l}\text { Acceleration of subsidies \& social assistance for the } \\
\text { poor and vulnerable households (basic necessities, } \\
\text { pre-employment cards, electricity tariff exemption, } \\
\text { etc.) }\end{array}$ & $\begin{array}{l}\text { Stimulus for expansi } \\
\text { middle class income } \\
\text { transportation, etc.) }\end{array}$ & $\begin{array}{l}\text { of consumption with a focus on } \\
\text { ourism, restaurants, }\end{array}$ \\
\hline & \multirow{2}{*}{$\begin{array}{l}\text { Business } \\
\text { Stimulus }\end{array}$} & $\begin{array}{l}\text { Ultra Micro Businesses and MSMEs } \\
\text { : } \quad \text { Deferred principal and interest loan repayment } \\
\text { : Tax interest subsidies } \\
\text { - } \text { Working capital loans guarantee } \\
\text { - Regional incentive funds }\end{array}$ & & \multirow{2}{*}{$\begin{array}{l}\text { Jumpstarting the Business } \\
\text { MSME working capital loan } \\
\text { guarantee } \\
\text { Distribution of SoEs working } \\
\text { capital loans } \\
\text { - Government fund placement } \\
\text { in banks affected by credit } \\
\text { restructuring } \\
\text { - Government fund placement } \\
\text { in SOEs } \\
\text { - Regional incentive funds } \\
\text { Support fund for Biodiesel } \\
\text { Program }\end{array}$} \\
\hline & & \multicolumn{2}{|l|}{$\begin{array}{l}\text { Industry and State-owned Enterprises (SoEs) } \\
\text { - Tax incentives } \\
\text { - Bailout funds } \\
\text { - } \text { Distribution of SoEs working capital loans } \\
\text { credit restructuring } \\
\text { - Support fund for Biodiesel Program }\end{array}$} & \\
\hline
\end{tabular}

Source: Ministry of Finance (2020)

lower than $50 \%$ awareness. In general, only a small share of micro-enterprises was aware of the programs, except the postponement of principal and interest installments. However, micro-enterprises' participation level for such program was very low because most of them did not use banking services yet. For them, the most attractive programs were mostly cash-based ones, such as working capital credit guarantees, loan interest subsidies, tax reduction incentives and emergency working capital stimulus.

Meanwhile, the small enterprises were mostly aware of all the programs except for the government's procurement of MSMEs products, SoEs cooperation with e-commerce for MSMEs' digitalization, and online training/capacity building - and their highest participation was recorded in tax reduction incentives and emergency working capital stimulus. As for the medium enterprises, they were mostly aware of all the programs and their highest participation was recorded in government's procurement of MSMEs products, SoEs cooperation with e-commerce for MSMEs' digitalization, online training/capacity building and tax reduction incentives.

When viewed by region, there are gaps between MSMEs operating in JawaBali and other areas. In general, MSMEs in Jawa-Bali were more informed about all PEN programs with the exception of SoEs assistance for MSMEs digitalization. This result indicates the unequal access to information, especially for those MSMEs locating further from Jawa and the capital. When viewed by gender, 
male-owned MSMEs were more informed about PEN programs with the exception of online training, government procurement prioritization for MSMEs and SoEs assistance for MSMEs digitalization.

Table 4: MSMEs' Awareness of the PEN Program (\%)

\begin{tabular}{|c|c|c|c|c|c|c|c|}
\hline \multirow[b]{2}{*}{ Program } & \multicolumn{3}{|c|}{ By Scale } & \multicolumn{2}{|c|}{ By Region } & \multicolumn{2}{|c|}{ By Gender } \\
\hline & Micro & Small & Medium & $\begin{array}{l}\text { Jawa and } \\
\text { Bali }\end{array}$ & $\begin{array}{l}\text { Rest of } \\
\text { Indonesia }\end{array}$ & Male & Female \\
\hline $\begin{array}{l}\text { Postponement of principal and } \\
\text { interest loan repayment for } \\
\text { MSMEs }\end{array}$ & 69.40 & 74.10 & 79.80 & 73.41 & 69.80 & 76.05 & 67.47 \\
\hline Tax incentives for MSMEs & 34.20 & 51.40 & 67.50 & 50.61 & 37.48 & 50.42 & 37.90 \\
\hline $\begin{array}{l}\text { Working capital credit } \\
\text { guarantee for MSMEs }\end{array}$ & 37.88 & 50.48 & 55.84 & 50.10 & 39.37 & 48.13 & 41.09 \\
\hline $\begin{array}{l}\text { Loan interest subsidy for } \\
\text { micro-enterprises and MSMEs }\end{array}$ & 35.91 & 57.59 & 62.34 & 51.94 & 42.49 & 53.14 & 41.17 \\
\hline $\begin{array}{l}\text { Emergency working capital } \\
\text { for ultra-micro businesses } \\
\text { and MSMEs }\end{array}$ & 49.61 & 63.13 & 62.34 & 62.03 & 50.76 & 60.88 & 51.88 \\
\hline $\begin{array}{l}\text { Government procurement } \\
\text { prioritization for MSMEs } \\
\text { products }\end{array}$ & 28.05 & 30.84 & 50.65 & 31.96 & 30.12 & 29.92 & 31.83 \\
\hline $\begin{array}{l}\text { SoEs cooperation with } \\
\text { e-commerce for MSMEs } \\
\text { digitalization }\end{array}$ & 25.19 & 34.70 & 48.05 & 27.82 & 32.84 & 29.92 & 31.70 \\
\hline Online training & 38.76 & 45.65 & 58.44 & 43.82 & 42.56 & 39.96 & 45.94 \\
\hline
\end{tabular}

MSMEs' awareness of a PEN program does not necessarily lead to program registration/accession. The survey revealed that several factors might affect MSMEs decision to access the program: perception of eligibility for the program, unable to meet the requirements documents/paperwork, unsure about the registration requirements and procedures, informally declined or discouraged by the local officials, or unsure about the location of the registration offices location.

However, Table 5 shows a large share of MSMEs that were informed about a PEN program would likely to apply, with the exception of the postponement of principal and interest loan repayment. This is because this particular program was channeled through banks and targeted MSMEs holding bank accounts, while a considerable share of MSMEs in Indonesia, especially the micro business, still did not use bank services yet. When viewed by gender, male-owned MSMEs were more encouraged to register to several programs, while female-owned MSMEs were more encouraged to apply to several other programs. When viewed by region, in general, MSMEs in Jawa-Bali showed a higher registration rate in almost all PEN programs.

When MSMEs decided to apply for the program, the success of the application was not granted automatically. Table 6 shows a rather low success rate for 
Table 5: MSMEs' Application of the PEN Program (\%)

\begin{tabular}{|c|c|c|c|c|c|c|c|}
\hline \multirow[b]{2}{*}{ Program } & \multicolumn{3}{|c|}{ By Scale } & \multicolumn{2}{|c|}{ By Region } & \multicolumn{2}{|c|}{ By Gender } \\
\hline & Micro & Small & Medium & $\begin{array}{l}\text { Jawa and } \\
\text { Bali }\end{array}$ & $\begin{array}{l}\text { Rest of } \\
\text { Indonesia }\end{array}$ & Male & Female \\
\hline $\begin{array}{l}\text { Postponement of principal and } \\
\text { interest loan repayment for } \\
\text { MSMEs }\end{array}$ & 34.90 & 61.80 & 70.30 & 51.88 & 39.28 & 48.83 & 43.02 \\
\hline Tax incentives for MSMEs & 82.90 & 78.10 & 84.60 & 87.29 & 73.13 & 81.17 & 80.30 \\
\hline $\begin{array}{l}\text { Working capital credit } \\
\text { guarantee for MSMEs }\end{array}$ & 75.26 & 74.29 & 67.44 & 80.60 & 66.82 & 75.44 & 72.56 \\
\hline $\begin{array}{l}\text { Loan interest subsidy for } \\
\text { micro-enterprises and MSMEs }\end{array}$ & 83.43 & 74.89 & 62.50 & 80.33 & 73.33 & 76.98 & 76.89 \\
\hline $\begin{array}{l}\text { Emergency working capital } \\
\text { for ultra-micro businesses } \\
\text { and MSMEs }\end{array}$ & 84.46 & 80.46 & 70.83 & 84.98 & 77.53 & 78.40 & 84.62 \\
\hline $\begin{array}{l}\text { Government procurement } \\
\text { prioritization for MSMEs } \\
\text { products }\end{array}$ & 71.74 & 67.72 & 79.49 & 73.02 & 69.66 & 67.63 & 73.94 \\
\hline $\begin{array}{l}\text { SoEs cooperation with } \\
\text { e-commerce for MSMEs } \\
\text { digitalization }\end{array}$ & 69.84 & 64.79 & 77.14 & 60.36 & 72.92 & 64.08 & 72.05 \\
\hline Online training & 68.75 & 74.59 & 81.82 & 71.86 & 73.23 & 75.27 & 70.64 \\
\hline
\end{tabular}

Source: Survey Data

Notes: Values above represent the percentage of respondents informed about the PEN program who would likely to apply.

Green boxes indicate higher than $75 \%$, while red boxes indicate lower than $50 \%$ awareness

the application of the postponement of principal and interest loan repayment program. This is because the decision-maker of this program was MSMEs' respective banks and each bank may have their risk assessment on the individual customer. Other factors that may deny MSMEs' application include incomplete documents/paperwork or poor credit history.

However, Table 6 also shows that most of MSMEs who successfully became program beneficiaries perceived that each program was helpful for their businesses. A small share of respondents who perceived that the programs were not too helpful argued that the program package was too small, too short duration or did not cater to their needs (did not match the assistance they needed most).

Table 7 shows MSMEs' sources of information regarding each of the PEN programs. Several sources of information were asked in the survey, including local government agencies, central government agencies, newspapers and online sources, television, business associations, business associates, family and relatives, non-government organizations, and business mentors. The source of information mentioned in each table cell is the main source of information of its respective program and respondent category. Dark grey cells indicate that a main source of information is very dominant (used as a reference by $>60 \%$ of respondents), light grey cells that a main source of information is used as a reference by $40-60 \%$ respondents, while white cells indicate that a source of information, despite referred as main source, was used only by $20-40 \%$ of the respondents. 
Table 6: Approval and Helpfulness Rate of PEN Program Application

\begin{tabular}{lcc}
\hline \hline Program & $\begin{array}{c}\text { Approval (\% of } \\
\text { respondents who } \\
\text { applied for the } \\
\text { program) }\end{array}$ & $\begin{array}{c}\text { Helpfulness (\% of } \\
\text { respondents whose } \\
\text { applications were } \\
\text { granted) }\end{array}$ \\
\hline $\begin{array}{c}\text { Postponement of principal and interest loan } \\
\text { repayment for MSMEs }\end{array}$ & $45.45 \%$ & $99.4 \%$ \\
Tax incentives for MSMEs & $78.72 \%$ & $99.1 \%$ \\
Working capital credit guarantee for MSMEs & $73.36 \%$ & $99.0 \%$ \\
Loan interest subsidy for micro-enterprises & $76.08 \%$ & $99.1 \%$ \\
$\quad \begin{array}{l}\text { and MSMEs } \\
\text { Emergency working capital for ultra-micro } \\
\text { businesses and MSMEs }\end{array}$ & $80.36 \%$ & $99.2 \%$ \\
Government procurement prioritization & $69.74 \%$ & $98.5 \%$ \\
$\quad$ for MSMEs products & $67.66 \%$ & $98.4 \%$ \\
SoEs cooperation with e-commerce for & $71.97 \%$ & $98.9 \%$ \\
$\quad \begin{array}{l}\text { MSMEs digitalization } \\
\text { Online training }\end{array}$ & & \\
\hline
\end{tabular}

Source: Survey Data

It appears that business associations were the most reliable source of information for micro and small businesses, while medium enterprises can afford other sources, mainly newspapers or other online sources. Hence, the socialization of future programs should closely involve business associations, especially those targeting micro and small business. When viewed by gender, business communities and associations were also the most reliable source of information in general, although male-owned MSMEs tend to have more varied sources of information. Interestingly, when viewed by region, business communities and associations were also the most reliable source of information in general, but MSMEs outside Jawa-Bali region tend to have more varied sources of information.

Figure 12 shows the surveyed MSMEs' suggestions for improvements of each of the PEN programs. In general, most respondents perceived the need for improvement in the program distribution to ensure that they reached the targeted beneficiaries, more widespread and massive socialization, broadening the targeted beneficiaries, and increasing the number of assistance packages.

The survey also asked MSMEs' suggestions and expectations for the future/follow-up programs. Should the pandemic persists longer than initially predicted, the MSMEs mostly need additional working capital, business coaching mainly related to digital marketing and financial management, production equipment, business regulation simplification, and lower cost of transportation to obtain cheaper inputs as well as lower cost of delivering their product to the market. When the pandemic is under control and the business recovers, those six programs are still the most demanded by MSMEs, with a slight difference in which business regulation simplification becomes the third most expected.

However, when viewed by sector, the order of importance of the expected future programs varies across sectors and some more specific programs appear 
Table 7: MSMEs' Main Source of Information Regarding the PEN Program

\begin{tabular}{|c|c|c|c|c|c|c|c|}
\hline \multirow[b]{2}{*}{ Program } & \multicolumn{3}{|c|}{ By Scale } & \multicolumn{2}{|c|}{ By Gender } & \multicolumn{2}{|c|}{ By Region } \\
\hline & Micro & Small & Medium & Male & Female & $\begin{array}{c}\text { Jawa and } \\
\text { Bali }\end{array}$ & $\begin{array}{c}\text { Rest of } \\
\text { Indonesia }\end{array}$ \\
\hline $\begin{array}{l}\text { Postponement of principal and } \\
\text { interest loan repayment for } \\
\text { MSMEs }\end{array}$ & NOS & $\mathrm{BCA}$ & NOS & NOS & BCA & BCA & NOS \\
\hline Tax incentives for MSMEs & BCA & BCA & BCA & BCA & $\mathrm{BCA}$ & BCA & NOS \\
\hline $\begin{array}{l}\text { Working capital credit } \\
\text { guarantee for MSMEs }\end{array}$ & $\mathrm{BCA}$ & $\mathrm{BCA}$ & BCA & BCA & BCA & $\mathrm{BCA}$ & NOS \\
\hline $\begin{array}{l}\text { Loan interest subsidy for ultra } \\
\text { micro-businesses and MSMEs }\end{array}$ & $\mathrm{BCA}$ & $\mathrm{BCA}$ & NOS & $\mathrm{BCA}$ & BCA & $\mathrm{BCA}$ & NOS \\
\hline $\begin{array}{l}\text { Emergency working capital } \\
\text { support for MSMEs }\end{array}$ & $\mathrm{BCA}$ & $\mathrm{BCA}$ & NOS & BCA & BCA & $\mathrm{BCA}$ & NOS \\
\hline $\begin{array}{l}\text { Government procurement } \\
\text { prioritization for MSMEs } \\
\text { products }\end{array}$ & BCA & BCA & NOS & BCA & BCA & BCA & BCA \\
\hline $\begin{array}{l}\text { SoEs cooperation with } \\
\text { e-commerce for MSMEs } \\
\text { digitalization }\end{array}$ & BCA & $\mathrm{BCA}$ & NOS & $\mathrm{BCA}$ & BCA & $\mathrm{BCA}$ & BCA \\
\hline Online training & BCA & BCA & NOS & BCA & BCA & $\mathrm{BCA}$ & BCA \\
\hline
\end{tabular}

Source: Survey Data

Notes: Note: NOS stands for Newspaper and Online Sources, BCA stands for Business Community and Association.

Dark grey indicates $>60 \%$, light grey indicates $40-60 \%$ and white indicates $20-40 \%$

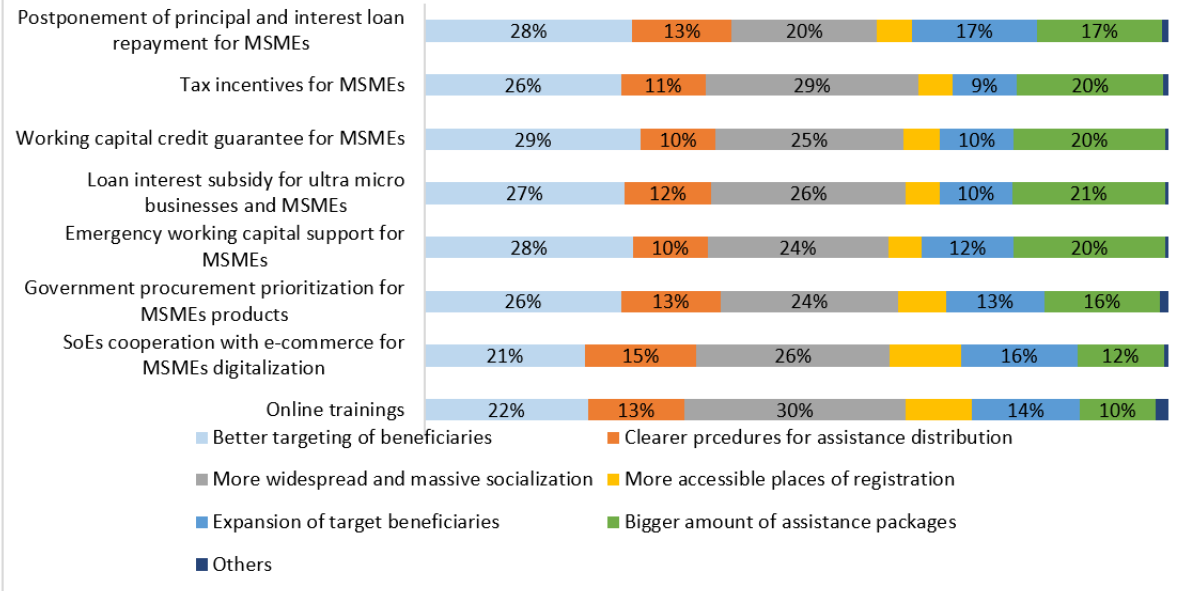

Figure 12: PEN Program Evaluation

Source: Survey data 
as among the most expected. The demanded support programs include business insurance, production technique and standardization, transportation infrastructure improvement, transportation cost subsidy, better internet access, and digital marketing skills.

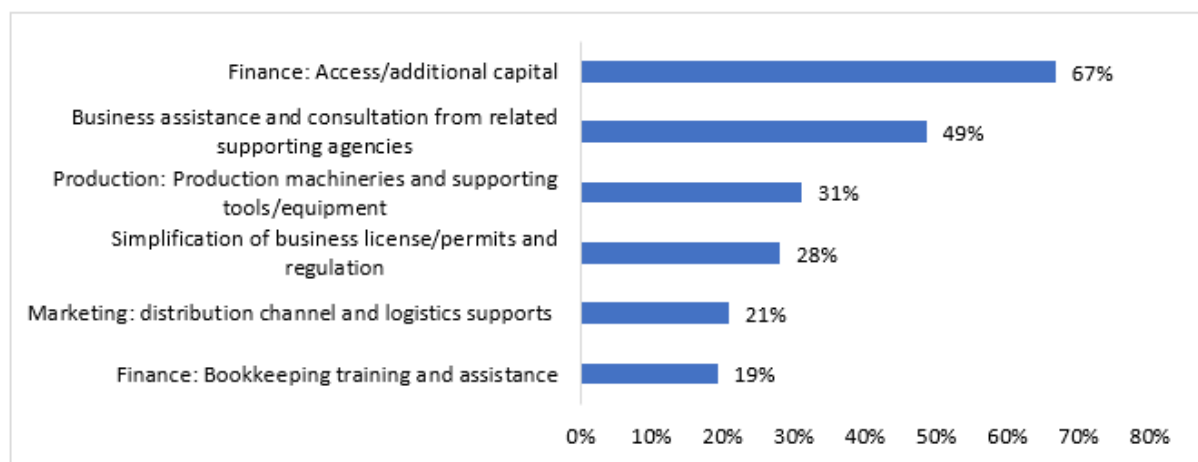

(a) During the pandemic

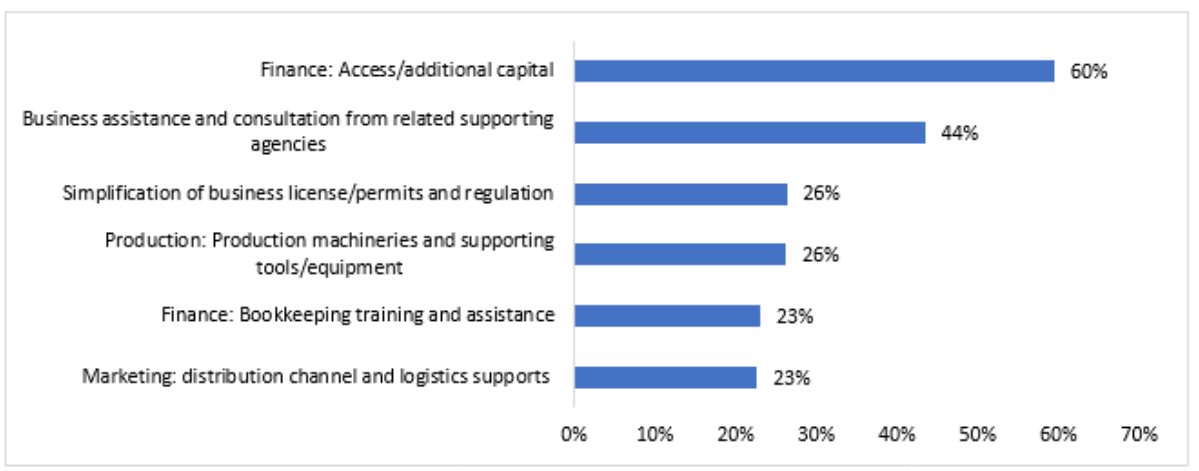

(b) During the business recovery

Figure 13: MSMEs' Suggestions for the Follow-up Programs

Source: Survey data

\section{Conclusion}

This study aims to investigate the impact of the COVID-19 pandemic on MSMEs in Indonesia and the effectiveness of government support. The results show that the pandemic severely affected MSMEs' performance in terms of revenue, profit, cash flow and employment. The government launched the economic recovery programs, a portion that targeted MSMEs. However, at the implementation level, the distribution of the program was hindered by several problems. 
The first and the most crucial issue hindering the program distribution is the unavailability of an accurate and up-to-date national MSME database. The business sectors and market segments entered by MSMEs are generally free or easy entry and exit, in which MSMEs are generally easy to leave a business when encountering obstacles and attempt new business lines. Further, since the pandemic outbreak in March 2020, it has been estimated that about $50 \%$ of MSMEs have experienced hardships with their businesses and some of them ended up in business closures. Unsurprisingly, the pandemic also created about 2.6-3.7 million new unemployment, part of which are expected to try to start new businesses. Most of these new businesses have not been registered with the Ministry of Cooperatives and SMEs, local government agencies, banks and other MSME community actors and activists. Hence, real and actual MSME database is mostly owned by MSMEs' communities and associations, entrepreneur communities, banks, and local government agencies. However, only a small share of MSMEs joined the business communities/associations and they cannot represent the MSMEs population as they tend to receive more financial and non-financial assistance from their respective associations than the overall MSMEs outside the community. Finally, socialization and distribution strategies of the PEN programs relied more on formal channels such as banks, causing non-formal and unbanked MSMEs were still left untouched. The survey results show that most microbusinesses were unaware of the PEN program or did not know how to access it.

The second problem hampering the effectiveness of the PEN programs was the gap between the distribution and the needs of MSMEs. The decline in MSMEs business already occurred since March-April 2020 and reached the lowest turnover point in April-May, while most recipient MSMEs only received the assistance in June or after. Further, exemption facilities and installment postponement for credit and multi-finance were provided for a 6-month period, but the pandemic that began since March was still ongoing until the end of 2020 (more than ten months). Finally, productive social aids for MSMEs were provided valid for four months, much shorter than the pandemic period which at the time of this report was written had lasted for more than eight months.

The findings of the study have several policy implications. First, most of the PEN programs for MSMEs should be extended in 2021 or as long as the pandemic persists, as most of the MSMEs recipients reported that the programs were very helpful in mitigating the impact of the pandemic. However, the survey results also showed that the assistance scheme offered is not yet fully in accordance with the needs of MSMEs, mainly because the problems faced by MSMEs are quite diverse. A number of MSMEs faced difficulty obtaining raw materials, such as those manufacturing medical devices and antiseptics. For such MSMEs, the main expected assistance is the access to the supply of raw materials, both from domestic and import. A number of MSMEs faced difficulty sending their products to the markets in other regions despite the strong demand. For such MSMEs, the main expected assistance is the ease of mobility of freight transport, transportation 
subsidies or package delivery subsidies. A number of MSMEs faced difficulty obtaining permission to continue operating and bring their employees to the production site. For such MSMEs, the main expected assistance is the certainty and ease of Industrial Permits for Operational and Mobility Activities (IOMKI). A number of MSMEs faced problems of decreasing turnover or liquidity. For such MSMEs, tax reduction and delay of credit payment offered by the government were considered appropriate. However, there was a problem at the implementation level, as some financial institutions did not fully implement these policies to their borrowers.

Second, future MSMEs assistance programs should also improve their socialization and registration procedure. The results show that MSMEs outside Jawa-Bali or those owned by female entrepreneurs were slightly less informed about the PEN programs, including its scheme, procedure/requirements, registration points and registration procedure.

Third, should the pandemic prolongs, the government needs to ensure MSMEs can continue to perform activities through the following policies. Subsidies or delays in payment of utility costs (electricity and clean water) can be provided, as the findings show that the majority of MSMEs tried to reduce spending during the pandemic. Free electricity facilities that were offered by the government (450 VA) can be extended. Second, assistance is required in order for MSMEs not to lay off their employees and be able to continue to pay workers' salaries. This can be done through salary subsidy, preceded by identification of workers, utilizing cross-institutional data. Aid for workers with salaries of less than IDR5 million can also be considered as they were probably not enrolled into the national social safety network. Connecting MSMEs with the market/buyers through technology can be prioritized. Some e-commerce platforms need to be constantly encouraged to purchase and trade MSMEs products. From the MSME side, the government can invite the associations to encourage MSMEs to join the marketplaces or, at least, make use of other information technologies (internet, WhatsApp, and social media) for marketing. The government can also provide stimulus in the form of subsidies for delivery/shipment of goods across regions as well as online campaigns targeted at increasing the number of MSMEs transactions.

Fourth, once the virus infection cases flatten and the pandemic begins to be under control, or at least by the time MSMEs have begun to adapt to the new normal, there are some supports that the government can provide to MSMEs. The government can help provide legal protection to MSMEs and their workers by expanding the legal assistance related to delays in the payment of employment rights, worker layoffs, and legal protections for workers who are prone to the pandemic in the form of safety law frameworks in the working places. MSMEs can be helped by the relaxation of regulations, especially in business licensing and product circulation permits. The easing of this regulation can help MSMEs return to normal operations faster and help individuals who want to set up new businesses. Capital access, credit, and taxation assistance can be extended. In the recovery period, MSMEs need capital to expand their business. In addition, the 
suspension of tax payments needs to be offered at least until MSMEs can reach a point such as prior to the pandemic or at the break-even point. Fifth, export market assistance can be enlarged. Indonesia's trade balance, which recorded a surplus of USD21.74 billion throughout 2020, in contrast to previous years that always recorded deficit, shows that the pandemic offers export opportunities due to slowing production activities of competing countries. In addition, the various international cooperation schemes that have been conducted by governments such as the Regional Comprehensive Economic Partnership (RCEP) and the Indonesia-Korea Comprehensive Economic Partnership (IK-CEPA) require the readiness of MSMEs to compete globally. Support can be given, for example, in the form of provision of export financing, insurance and guarantee for businesses that aspire to expand into the international market.

\section{References}

[1] ABDSI. (2020, 20 March). Siaran pers ABDSI terkait antisipasi dan penanganan dampak pandemi Corona terhadap UMKM. Retrieved 15 December 2020 from https://www.abdsi.id/ siaran-pers-abdsi-terkait-antisipasi-dan-penanganan-dampak-pandemi-corona/.

[2] Baldwin, R. E., \& di Mauro, B. W. (Eds.) (2020). Mitigating the COVID economic crisis: Act fast and do whatever it takes. CEPR Press. Retrieved 2 January 2021 from https://voxeu.org/content/ mitigating-covid-economic-crisis-act-fast-and-do-whatever-it-takes.

[3] Bank Indonesia. (2021, 5 February). Pertumbuhan ekonomi Indonesia triwulan IV2020 melanjutkan perbaikan. Siaran Pers No. 23/33/DKom. Retrieved 10 February 2021 from https://www.bi.go.id/id/publikasi/ruang-media/news-release/Pages/ sp_233321.aspx.

[4] Bhasin, B. B., \& Venkataramany, S. (2010). Globalization of entrepreneurship: Policy considerations for SME development in Indonesia. International Business $\mathcal{E}$ Economics Research Journal (IBER), 9(4), 95-104. doi:https://doi.org/10.19030/iber.v9i4.557.

[5] BPS-Statistics Indonesia. (2014). Industri Statistics.

[6] BPS-Statistics Indonesia. (2020, 5 November). Keadaan ketenagakerjaan Indonesia Agustus 2020 [Agustus 2020: Tingkat Pengangguran Terbuka (TPT) sebesar 7,07 persen]. Berita Resmi Statistik No. 86/11/Th. XXIII. Retrieved 21 March 2021 from https://www.bps.go.id/pressrelease/2020/11/05/1673/ agustus-2020--tingkat-pengangguran-terbuka--tpt--sebesar-7-07-persen.html.

[7] BPS-Statistics Indonesia. (2021, 5 May). Pertumbuhan ekonomi Indonesia Triwulan I-2021 [Ekonomi Indonesia Triwulan I-2021 turun 0,74 persen (y-on-y)]. Berita Resmi Statistik No. 36/05/Th. XXIV. Retrieved 10 May 2021 from https://www.bps.go.id/pressrelease/2021/05/05/1812/ ekonomi-indonesia-triwulan-i-2021-turun-0-74-persen--y-on-y-.html.

[8] Cowling, M., Brown, R., \& Rocha, A. (2020). Did you save some cash for a rainy COVID-19 day? The crisis and SMEs. International Small Business Journal, 38(7), 593604. doi: https://doi.org/10.1177/0266242620945102.

[9] detikNews. (2020, 2 December). 9,77 juta orang kena PHK, MPR soroti SDM dan literasi teknologi. Retrieved 15 January 2021 from https://news.detik.com/berita/ d-5278957/977-juta-orang-kena-phk-mpr-soroti-sdm-dan-literasi-teknologi. 
[10] Hill, H. (2002). Old policy challenges for a new administration: SMEs in Indonesia. In C. Harvie \& B.-C. Lee (Eds.), The Role of SMEs in National Economies in East Asia, Edward Elgar, pp. 158-176.

[11] ILO. (2020). The clock is ticking for survival of Indonesian enterprises, jobs at risk: Key findings of the ILO SCORE Indonesia COVID-19 enterprise survey. Research Brief. International Labour Organization. Retrieved 8 July 2021 from https:/ /www. ilo.org/jakarta/whatwedo/publications/WCMS_745055/lang--en/index.htm.

[12] Mavrodieva, A. V., Budiarti, D. S., Yu, Z., Pasha, F. A., \& Shaw, R. (2019). Governmental incentivization for SMEs' engagement in disaster resilience in Southeast Asia. International Journal of Disaster Risk Management, 1(1), 32-50. doi: https://doi.org/10.18485/ijdrm.2019.1.1.2.

[13] Ministry of Cooperatives and SMEs. (2020). Tabel - 1. Perkembangan Data Usaha Mikro, Kecil, Menengah (UMKM) dan Usaha Besar (UB) Tahun 2018 - 2019. Retrieved 25 February 2021 from https://www.kemenkopukm.go.id/uploads/laporan/1617162002 SANDINGAN_DATA_UMKM_2018-2019.pdf.

[14] Ministry of Finance. (2020, 15 July). Realisasi program PEN tahun 2020 capai Rp575,8 triliun. Retrieved 20 July 2021 from https:/ /www.kemenkeu.go.id/publikasi/berita/ realisasi-program-pen-tahun-2020-capai-rp575-8-triliun/.

[15] Reardon, T., Mishra, A., Nuthalapati, C. S., Bellemare, M. F., \& Zilberman, D. (2020). COVID-19's disruption of India's transformed food supply chains. Economic and Political Weekly, 55(18), 18-22.

[16] Rekarti, E., Doktoralina, C. M., \& Saluy, A. B. (2018). Development model of marketing capabilities and export performance of smes: a proposed study. European Journal of Business and Management, 10(22), 107-144.

[17] Revindo, M. D., \& Gan, C. (2017). Rural microfinance banking viability and outreach: A case of Bank Rakyat Indonesia. In C. Gan \& G. Nartea (Eds.), Microfinance in Asia, World Scientific, pp. 337-356.

[18] Revindo, M., Gan, C., \& Nguyen, C. (2017). Internationalization strategy and process: Evidence from Indonesian SMEs. World Journal of Management, 8(1), 59-74. doi: https://doi.org/10.21102/wjm.2017.03.81.05.

[19] Revindo, M. D., Gan, C., \& Massie, N. W. G. (2019a). Factors affecting propensity to export: The case of Indonesian SMEs. Gadjah Mada International Journal of Business, 21(3), 263-288. doi: http:/ /dx.doi.org/10.22146/gamaijb.41022.

[20] Revindo, M. D., Indrawati, S. M., \& Hambali, S. (2019b). The role of networking in the internationalization of Indonesian SMEs. JEJAK: Jurnal Ekonomi dan Kebijakan, 12(2), 421-445. doi: https://doi.org/10.15294/jejak.v12i2.21821.

[21] Revindo, M. D., Indrawati, S. M., \& Massie, N. W. G. (2019c). Policy options to remove export barriers encountered by Indonesian SMEs. Jurnal Ekonomi Indonesia, 8(1), 37-69. doi: https:/ /doi.org/10.52813/jei.v8i1.12.

[22] Rosavina, M., Rahadi, R. A., Kitri, M. L., Nuraeni, S., \& Mayangsari, L. (2019). P2P lending adoption by SMEs in Indonesia. Qualitative Research in Financial Markets, 11(2), 260-279. doi: https://doi.org/10.1108/QRFM-09-2018-0103.

[23] Sandee, H. M., Kities Andadari, R., \& Sulandjari, S. (2000). Small firm development during good times and bad: The Jepara furniture industry. In C. Manning \& P. van Diermen (Eds.), Indonesia in transition: Social aspects of reformasi and crisis, Institute of Southeast Asian Studies, pp. 184-200.

[24] Sulistiyani, E., \& Rahardja, E. (2018). Examining the effect of transformational leadership, extrinsic reward, and knowledge sharing on creative performance of Indonesian 
SMEs. Quality-Access to Success, 19(167), 63-67.

[25] Suryahadi, A., Al Izzati, R., \& Suryadarma, D. (2020). The impact of COVID-19 outbreak on poverty: An estimation for Indonesia. SMERU Working Paper April 2020. The SMERU Research Institute. https://www.smeru.or.id/sites/default/files/ publication/wp_covid19impact_draft.pdf.

[26] Susan, M. (2020). Financial literacy and growth of micro, small, and medium enterprises in West Java, Indonesia. In W. A. Barnett \& B. S. Sergi (Eds.), Advanced Issues in the Economics of Emerging Markets (International Symposia in Economic Theory and Econometrics, vol. 27), Emerald Publishing Limited, pp. 39-48. doi: https://doi.org/10.1108/S1571-038620200000027004.

[27] Tambunan, T. (2007). SME development in Indonesia with reference to networking, innovativeness, market expansion and government policy. In H. Lim (ed.), SME in Asia and globalization, vol. 5, ERIA Research Project Report, pp. 99-131.

[28] Tambunan, T. (2009). Export-oriented small and medium industry clusters in Indonesia. Journal of Enterprising Communities: People and Places in the Global Economy, 3(1), 25-58. doi: https:/ /doi.org/10.1108/17506200910943661.

[29] ter Wengel, J., \& Rodriguez, E. (2006). SME export performance in Indonesia after the crisis. Small Business Economics, 26(1), 25-37. doi: https://doi.org/10.1007/s11187004-6491-y. 
this page intentionally left blank 